\title{
National Emission Standards for Hazardous Air Pollutants Calendar Year 2000
}

\author{
June 2001
}

U.S. Department of Energy

National Nuclear Security Administration

Nevada Operations Office

Las Vegas, Nevada 


\section{DISCLAIMER}

Reference herein to any specific commercial product, process, or service by trade name, trademark, manufacturer, or otherwise, does not necessarily constitute or imply its endorsement, recommendation, or favoring by the U.S. Government or any agency thereof or its contractors or subcontractors.

This report has been reproduced directly from the best available copy.

Available for sale to the public from:

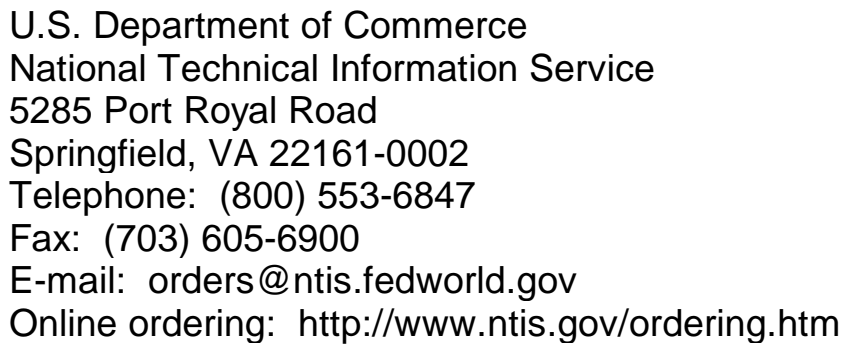

Available electronically at http://www.doe.gov/bridge.

Available for a processing fee to the U.S. Department of Energy and its contractors, in paper, from:

U.S. Department of Energy

Office of Scientific and Technical Information

P.O. Box 62

Oak Ridge, TN 37831-0062

Telephone: (865) 576-8401

Fax: (865) 576-5728

E-mail: reports@adonis.osti.gov 


\section{National Emission Standards for Hazardous Air Pollutants \\ Calendar Year 2000}

By

Robert F. Grossman

Edited By

Yvonne E. Townsend

June 2001

Work Performed Under

Contract No.

DE-AC08-96NV11718

Prepared by:

Bechtel Nevada

Post Office Box 98521

Las Vegas, Nevada 89193-8521 
This page intentionally left blank 


\section{TABLE OF CONTENTS}

Page

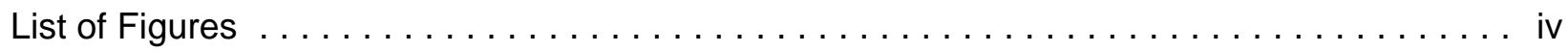

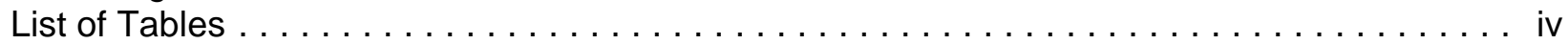

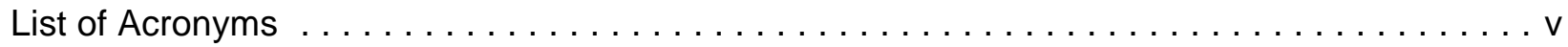

Operations Office and Site Information $\ldots \ldots \ldots \ldots \ldots \ldots \ldots \ldots \ldots \ldots \ldots \ldots \ldots \ldots \ldots \ldots \ldots \ldots$

Section I

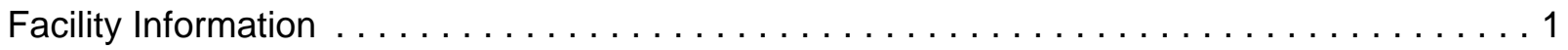

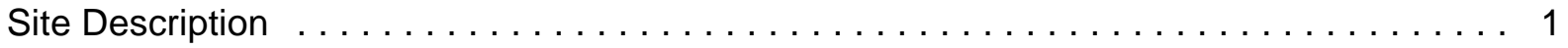

Source Description .............................

Section II

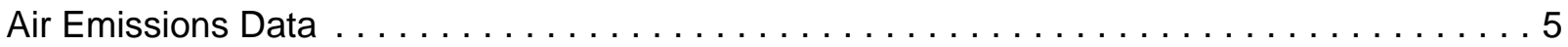

Section III

Dose Assessments . ...................................

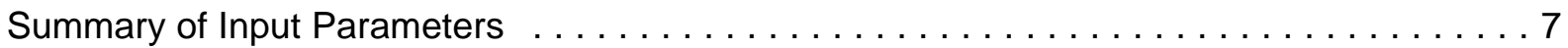

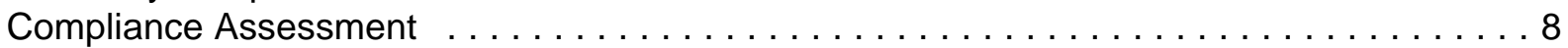

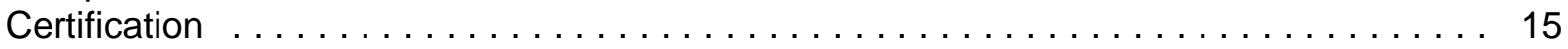

Section IV

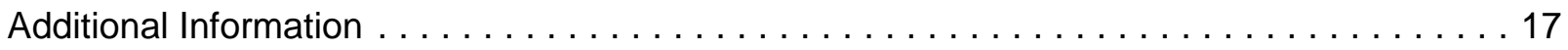

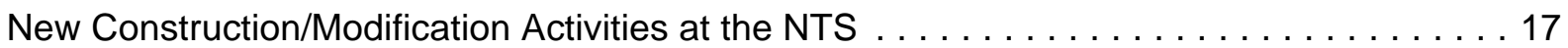

Unplanned Releases During Calendar Year (CY) $2000 \ldots \ldots \ldots \ldots \ldots \ldots \ldots \ldots \ldots \ldots \ldots$

Sources of Diffuse or Fugitive Emissions $\ldots \ldots \ldots \ldots \ldots \ldots \ldots \ldots \ldots \ldots \ldots \ldots \ldots \ldots \ldots \ldots \ldots$

\section{LIST OF APPENDICES}

Appendix A Public Dose Calculations for the Atlas Tritium Incident $\ldots \ldots \ldots \ldots \ldots \ldots$ A-1

Appendix B Emissions from Containment Ponds ...................... B-1

Appendix C Potential Radionuclide Emissions from Radioanalytical Laboratories . ....... C-1

Appendix D Atmospheric Tritium Emissions from Diffuse Sources ................ D-1

Appendix E Resuspended Plutonium from Yucca Flat and other Areas ............ E-1

Appendix F Identification and Justification for the Development of Meteorological

Data used as Input to CAP88-PC . . . . . . . . . . . . . . . F-1

Appendix G Dose Assessment for Modification of Area 6 Device Assembly Facility . . . . G-1

Appendix H Supplemental Information

Appendix I References $\ldots \ldots \ldots \ldots \ldots \ldots \ldots \ldots \ldots \ldots \ldots \ldots \ldots \ldots \ldots . . .1$

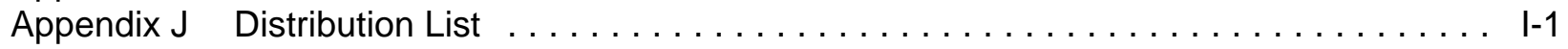




\section{LIST OF FIGURES}

Page

Figure 1.0

Figure 2.0

Figure 3.0

Figure 4.0

Figure 5.0

Figure F.1
Map of the NTS and Surrounding Areas . . . . . . . . . . . . . . 19

Nuclear Testing Areas on the NTS . . . . . . . . . . . . . . . . 20

Photograph of Tunnel Containment Ponds . . . . . . . . . . . . . 21

Photograph of the Building 650 Hood Ventilation Stacks Seen

from Above . . . . . . . . . . . . . . . . . . . . 22

Locations of Potential Diffuse Sources of Plutonium on and

Near the NTS . . . . . . . . . . . . . . . . . . . . . 23

Location of Meteorological Data Acquisition System (MEDA)

Stations on the NTS

\section{LIST OF TABLES}

Table 1.0 Estimated Inventory of ${ }^{239+240} \mathrm{Pu}$ and ${ }^{241} \mathrm{Am}$ in Surface Soil $(0$ to $5 \mathrm{~cm})$

at Studied Sites ......................... 4

Table 2.0 Summary of Annual Air Emissions Data by Source ${ }^{(a)}$ (Multiply Ci by 37

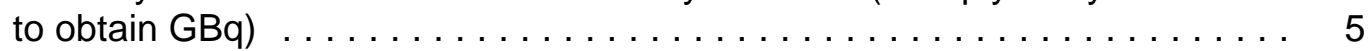

Table 3.0

Total Emissions for CY 2000 (Multiply Ci by 37 to obtain GBq) . . . . . . . 6

Table 4.0

Table 5.0

Table 6.0

Summary of CY 2000 CAP88-PC Calculations of EDE to the MEI Offsite,

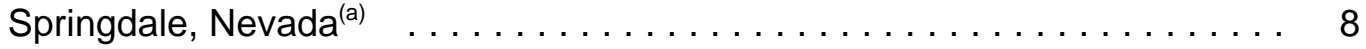

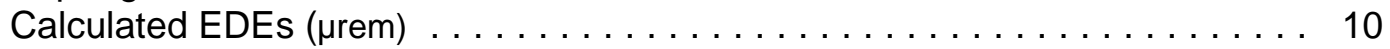

Comparison of EDEs Calculated by CAP88-PC with EDEs Calculated from

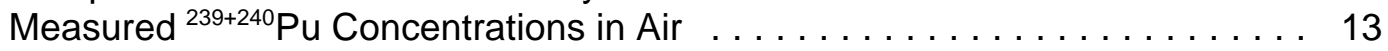

Table D.1 Airborne Tritium Sampling Results During CY - 2000 . . . . . . . . . . . D-2

Table E.1 Calculated Emissions from Resuspension of Plutonium and Americium in NTS

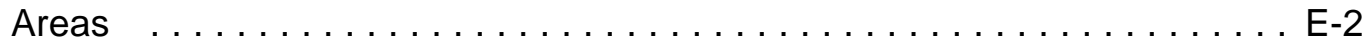




\section{LIST OF ACRONYMS}

$\begin{array}{ll}\text { ARL/SORD } & \text { Air Resources Laboratory Special Operations and Research Division } \\ \text { ASL } & \text { Analytical Services Laboratory } \\ \text { BN } & \text { Bechtel Nevada } \\ \text { CAP88-PC } & \text { Clean Air Package 1988 (EPA software program for estimating doses) } \\ \text { CFR } & \text { Code of Federal Regulations } \\ \text { CY } & \text { Calendar Year } \\ \text { DAF } & \text { Device Assembly Facility } \\ \text { DOE } & \text { U.S. Department of Energy } \\ \text { DRA } & \text { Desert Rock Meteorological Observatory } \\ \text { EDE } & \text { Effective Dose Equivalent } \\ \text { EPA } & \text { U.S. Environmental Protection Agency } \\ \text { FFACO } & \text { Federal Facilities Agreement and Consent Order } \\ \text { HTO } & \text { Tritiated Water } \\ \text { JASPER } & \text { Joint Actinide Shock Physics Experimental Research } \\ \text { LLW } & \text { Low-level Radioactive Waste } \\ \text { MDC } & \text { Minimum Detectable Concentration } \\ \text { MEDA } & \text { Meteorological Data Acquisition System } \\ \text { MEI } & \text { Maximally Exposed Individual } \\ \text { MIDNET } & \text { Meteorological Data Network } \\ \text { NAFR } & \text { Nellis Air Force Range } \\ \text { NESHAP } & \text { National Emission Standard for Hazardous Air Pollutants } \\ \text { NLVF } & \text { North Las Vegas Facility } \\ \text { NNSA/NV } & \text { U.S. Department of Energy, National Nuclear Security Administration Nevada } \\ & \text { Operations Office } \\ \text { NOAA } & \text { National Oceanic and Atmospheric Administration } \\ \text { NTS } & \text { Nevada Test Site } \\ \text { RWMS } & \text { Radioactive Waste Management Site } \\ \text { RWMS-3 } & \text { Radioactive Waste Management Site, Area 3 } \\ \text { RWMS-5 } & \text { Radioactive Waste Management Site, Area 5 } \\ \text { STAR } & \text { Stability Array - (grouping of meteorological data) } \\ \text { TRU } & \text { Transuranic - (nuclides with atomic numbers greater than uranium) } \\ \text { UCC } & \text { Yucca Flat Meteorological Observatory } \\ \text { WEF } & \text { Waste Evaluation Facility } \\ & \\ & \end{array}$


This page intentionally left blank 


\section{U.S. Department of Energy \\ National Nuclear Security Administration \\ Nevada Operations Office \\ Air Emissions Annual Report \\ (under Subpart H, Title 40 Code of Federal Regulations [CFR] 61.94) \\ Calendar Year (CY) 2000}

Site Name: $\quad$ Nevada Test Site

\section{Operations Office Information}

Office: $\quad$ U.S. Department of Energy, National Nuclear Security Administration Nevada Operations Office

Address: $\quad$ P. O. Box 98518

Las Vegas, NV 89193-8518

Contact: $\quad$ Kenneth A. Hoar

Phone:(702) 295-1428

Director, Environment, Safety and Health Division

\section{Site Information}

Operator: Bechtel Nevada

Address: $\quad$ P. O. Box 98521

Las Vegas, NV 89193-8521

Contact: $\quad$ Paul W. Tomiczek, Jr.

Phone: (702) 295-2882

Assistant General Manager, Environmental Management 
This page intentionally left blank 


\section{SECTION I \\ FACILITY INFORMATION}

\section{SITE DESCRIPTION}

The Nevada Test Site (NTS) is operated by the U.S. Department of Energy, National Nuclear Security Administration Nevada Operations Office (NNSA/NV) as the site for nuclear weapons testing, now limited to readiness activities, experiments in support of the national Stockpile Stewardship Program, and the activities listed below. It is located in Nye County, Nevada, with the southeast corner about $105 \mathrm{~km}$ (65 mi) northwest of Las Vegas, Nevada. The NTS covers about $3,561 \mathrm{~km}^{2}\left(1,375 \mathrm{mi}^{2}\right)$, an area larger than Rhode Island. Its size is about 46 to $56 \mathrm{~km}$ (28 to $35 \mathrm{mi}$ ) east to west and from 64 to $88 \mathrm{~km}$ ( 40 to $55 \mathrm{mi})$ north to south. The NTS is surrounded, except on the south side, by public exclusion areas (Nellis Air Force Range [NAFR]) that provide another 24 to $104 \mathrm{~km}$ (15 to $65 \mathrm{mi}$ ) between the NTS and public lands (Figure 1.0). The NTS is characterized by desert valley and Great Basin mountain topography, with a climate, flora, and fauna typical of the southwest deserts. Population density within $150 \mathrm{~km}$ (93 mi) of the NTS is only about 0.2 persons per square kilometer, excluding the Las Vegas area. Restricted access, low population density in the surrounding area, and extended wind transport times are advantageous factors for the activities conducted at the NTS. Surface waters are scarce on the NTS, and there is great depth to slow-moving groundwater.

\section{SOURCE DESCRIPTION}

The sources of radionuclides include current and previous activities conducted on the NTS. Figure 2.0 is a map of the NTS that shows the areas used for such activities. The NTS was the primary location for testing of nuclear explosives in the Continental U.S. between 1951 and 1992. Historical testing has included (1) atmospheric testing in the 1950s and early 1960s, (2) earth-cratering experiments, and (3) open-air nuclear reactor and rocket engine testing. Since the mid-1960s, testing of nuclear explosive devices has occurred underground in drilled vertical holes or in mined tunnels (U.S. Department of Energy [DOE 1996a]). No such tests have been conducted since September 23, 1992 (DOE 2000). Limited non-nuclear testing includes spills of hazardous materials at the Hazardous Materials Spill Center, private technology development, aerospace and demilitarization activities, and site remediating activities. Processing of radioactive materials is limited to laboratory analyses, and handling is restricted to transport, storage, and assembly of nuclear explosive devices and operation of radioactive waste management sites (RWMSs) for low-level radioactive and mixed waste (DOE 1996a). Monitoring and evaluation of the various activities conducted onsite indicate that the potential sources of offsite radiation exposure in 2000 were releases from (1) evaporation of tritiated water (HTO) from containment ponds that receive drainage water from $\mathrm{E}$ Tunnel in Area 12 and from discharges of Well RNM-2s into the CAMBRIC ditch, (2) onsite radioanalytical laboratories, (3) the Area 5 RWMS (RWMS-5) facility, and (4) diffuse sources of tritium and resuspension of plutonium. The following sections present a general description of the present sources on the NTS.

At the North Las Vegas Facility (NLVF), operated for NNSA/NV by Bechtel Nevada (BN), there was an unusual occurrence in 1995 that led to a very small potential exposure to an offsite person. The incident involved the release of tritium as HTO. The HTO emission has continued (probably deemanation of building materials) at lower levels, even after cleanup activities in November and December 1997. A description of the incident and the method of calculating the effective dose equivalent (EDE) for offsite exposure are set forth in Appendix A. 


\section{Tunnel Operations}

Nuclear tests have been conducted within tunnel complexes mined into the Rainier Mesa region and in Areas 15 and 16. When tests were conducted, purging gases from the tunnel occasionally resulted in releases of radioactivity, and contaminated water drained from the tunnels into containment ponds (ERDA 1977). No such activities have occurred since 1992.

\section{Containment Ponds}

Water contaminated with radionuclides seeped from the tunnels in Area 12 and was collected in containment ponds where some evaporated and some seeped into the soil. A photograph of tunnel containment ponds is provided in Figure 3.0. The tunnels have been sealed, but water continues to seep from $E$ Tunnel. The only radiological contaminant which produces a measurable air emission from evaporation of the water is ${ }^{3} \mathrm{H}$ (as HTO). Calculation of the source term for this emission is described in Appendix B.

To characterize the groundwater regime under the NTS, suitable wells are being drilled and existing wells recompleted in the vicinity of certain underground tests and at other locations on the NTS, as determined by hydrologists. During these drilling operations, contaminated water may be pumped from the wells. This water is diverted to lined containment ponds if the tritium level exceeds $2 \times 10^{5} \mathrm{pCi} / \mathrm{L}$, as required by the state and explained in the Underground Test Area Program (DOE 1996a). During CY 2000, this activity was suspended.

Water contaminated primarily with tritium is sometimes pumped from Well RMNS-2 into the CAMBRIC ditch as part of a special study. This was done in CY 2000 for Project Osprey. Calculations for this activity are described in Appendix B.

\section{Laboratories}

Radiological analyses are conducted in laboratories located in Building 650, Mercury; Building CP-95A; and the Device Assembly Facility in Area 6. This work is no longer conducted in Building 5-6 at the Waste Management Facility in Area 5. Because these facilities process environmental samples, very little radioactivity passes through them. However, there is potential for some radionuclides to be discharged into the atmosphere through the hood ventilation system during sample processing, particularly of spiked samples, or from loss of radioactive standards. Figure 4.0 is a photograph of the Building 650 hood ventilation stacks seen from above. The source term for these laboratories is described in Appendix C. In general, evaporation and spills from samples containing HTO, radioiodines, or noble gases are conservatively estimated by assuming all such materials are released. Radioactive standards are the principal sources for these releases. Non-volatile materials are controlled by keeping their inventory below the possession limits set forth in Title 40 CFR 61 (CFR 1989).

\section{Radioactive Waste Management Sites}

The RWMSs in Area 3 (RWMS-3) and RWMS-5 are used for the disposal of low-level radioactive waste (LLW). The RWMS-5 is also used for accumulation of mixed waste and storage of transuranic (TRU) and mixed TRU wastes. Disposal is accomplished by the use of pits and trenches; concrete pads are used for temporary storage of certain wastes. At RWMS-5, only packaged, dry wastes are accepted for disposal. The facility is considered a diffuse source of radiological effluents. The only radioactive effluent detected by the various types of samplers surrounding the site is HTO in atmospheric moisture. The calculation of the HTO source term is explained in Appendix D. The RWMS-3 LLW site is in a location where the surrounding surface 
soil has been contaminated by past nuclear tests. The resuspension of this soil by wind or vehicular activity results in above background levels of plutonium being detected in air samples collected inside and outside the perimeter fence.

\section{Surface Areas Contaminated with Plutonium or Tritium}

Surface soils in certain areas on and off of the NTS were contaminated with plutonium and/or tritium from either nuclear device safety, atmospheric, or cratering tests, using nuclear explosives. An investigation of these areas during the Nevada Applied Ecology Group studies, updated by the Desert Research Institute (DOE 1991), developed the inventories of plutonium shown in Table 1.0. These areas could become sources of plutonium exposure if the contaminated soils were to be resuspended, e.g., during surface cleanup, construction, vehicular travel, or similar activities. Figure 5.0 is a map showing the approximate locations of the nuclear device safety tests on or near the NTS. There are air samplers at or near most of these onsite areas. Plutonium analyses of the glass-fiber filters from these samplers indicate that the majority of the results are less than the minimum detectable concentration (MDC) and most of those are even less than the two standard deviation (2s) counting error. The results that are different are from air samplers in areas where operational activities can cause contaminated surface soil to become resuspended. These areas are considered diffuse sources of radioactive effluents, although only americium and plutonium are detectable. The derivation of the source term for and reason for selection of americium and plutonium from contaminated areas is explained in Appendix E.

Tritium emanation from the cratering tests SEDAN and SCHOONER is detectable in atmospheric moisture samples collected on molecular sieves by special air samplers. Derivation of the source term for these locations is described in Appendix D.

\section{Federal Facilities Agreement and Consent Order (FFACO)}

Under the FFACO between NNSA/NV and the state (FFACO 1996), contamination generated by historical NTS activities is being addressed. Two surface areas on the NAFR have had partial source removal so far. These surface areas are DOUBLE TRACKS in 1996 and CLEAN SLATE I in 1997. This resulted in a decrease in offsite EDE. The monitoring plan for such activities envisages continued air sampling until the concentration in air returns to background levels. The clean up of DOUBLE TRACKS (DOE 1997a) and CLEAN SLATE I (DOE 1997b) areas resulted in removal of $5.12 \mathrm{Ci}$ and $5.65 \mathrm{Ci}$ of ${ }^{239+240} \mathrm{Pu}$, respectively, based upon radiation measurements of the soil as it was bagged for transporting to burial in the RWMS-3, not by mobile surveys conducted by the Remote Sensing Laboratory with the KIWI-I vehicle. The amounts removed are within the 95 percent confidence interval of the 1.7 to $6.0 \mathrm{Ci}$ estimated for each of these two locations. 
Table 1.0 Estimated Inventory of ${ }^{239+240} \mathrm{Pu}$ and ${ }^{241} \mathrm{Am}$ in Surface Soil $(0$ to $5 \mathrm{~cm}$ ) at Studied Sites

\begin{tabular}{|c|c|c|c|c|}
\hline \multicolumn{5}{|c|}{ Onsite Areas Studied $^{(\mathrm{a})}$} \\
\hline Area & Area $\left(\mathrm{mi}^{2}\right)$ & ${ }^{241} \mathrm{Am}(\mathrm{Ci})$ & ${ }^{238} \mathrm{Pu}(\mathrm{Ci})$ & ${ }^{239} \mathrm{Pu}(\mathrm{Ci})$ \\
\hline 1 & 26.5 & 4.2 & 6.5 & $24^{(b)}$ \\
\hline 2 & 19.7 & 2.9 & 8.6 & $22^{(b)}$ \\
\hline 3 & 32.3 & 4.6 & 3.1 & 37 \\
\hline 4 & 16.0 & 6.6 & 13 & $40^{(\mathrm{b})}$ \\
\hline 5 & 2.9 & 0.6 & 0.1 & $4.8^{(\mathrm{b})}$ \\
\hline 6 & 32.3 & 1.7 & 3.3 & $8.4^{(\mathrm{b})}$ \\
\hline 7 & 19.3 & 2.2 & 0.6 & $16^{(\mathrm{b})}$ \\
\hline 8 & 13.9 & 17 & 8.0 & 110 \\
\hline 9 & 20.0 & 4.2 & 2.2 & 89 \\
\hline 10 & 20.0 & 19 & 19 & 110 \\
\hline 11 & 4.0 & 3.3 & 0.5 & 29 \\
\hline 12 & 39.6 & 5.7 & 8.5 & $39^{(b)}$ \\
\hline 15 & 35.3 & 8.0 & 7.8 & $63^{(b)}$ \\
\hline 16 & 14.3 & 0.7 & 1.5 & $3.7^{(\mathrm{b})}$ \\
\hline 17 & 31.4 & 2.8 & 4.5 & $18^{(b)}$ \\
\hline 18 & 27.3 & 19 & 5.6 & 100 \\
\hline 19 & 148.3 & 21 & 32 & $140^{(\mathrm{b})}$ \\
\hline 20 & 6.2 & 23 & 30 & 41 \\
\hline 25 & 0.9 & 0 & 0 & 0 \\
\hline 26 & 0.2 & 0 & 0 & 0 \\
\hline 30 & 0.3 & 3.2 & 4.5 & $14^{(\mathrm{b})}$ \\
\hline \multicolumn{5}{|c|}{ Offsite Areas Studied (c) } \\
\hline Area 13 & 1.55 & $\mathrm{~N} / \mathrm{A}$ & $\mathrm{N} / \mathrm{A}$ & 46 \\
\hline CLEAN SLATE II & 0.18 & $\mathrm{~N} / \mathrm{A}$ & $\mathrm{N} / \mathrm{A}$ & 17 \\
\hline CLEAN SLATE III & 0.67 & $N / A$ & $\mathrm{~N} / \mathrm{A}$ & 37 \\
\hline
\end{tabular}

N/A Not available.

(a) (DOE 1991).

(b) Used for the first time in the resuspension calculations. Re-evaluation of the above referenced report indicated that these levels were probably the result of fallout from nuclear tests in surrounding areas.

(c) Safety/transport tests of nuclear devices (DOE 1992). 


\section{SECTION II \\ AIR EMISSIONS DATA}

Each potential source of NTS emissions was characterized by one of the following methods:

(1) monitoring methods and procedures previously developed at the NTS; (2) a yearly radionuclide inventory of the sources in laboratories, assuming that volatile radionuclides are released to the environment; (3) the measurement of tritiated water (as $\mathrm{HTO}_{\text {or }} \mathrm{T}_{2} \mathrm{O}$ ) concentration in liquid effluents discharged to containment ponds and assuming all the effluent evaporates over the course of the year to become an air emission; (4) use of resuspension calculations; and (5) using a combination of environmental measurements and Clean Air Package 1988 air dispersion model (CAP88-PC) (U.S. Environmental Protection Agency [EPA] 1992) to calculate emissions. Appendices $\mathrm{A}$ through $\mathrm{E}$ describe the methods used to determine the emissions from the sources listed in Section I. In accordance with Title 40 CFR 61.93.(b)(4), (CFR 1989) no credit was taken for pollution control equipment in determining air emissions.

The emissions for National Emission Standards for Hazardous Air Pollutants (NESHAPs), reporting are listed in Table 2.0. These emissions are very conservative (worst-case) and are used in Section III to calculate the EDE to the maximally exposed individual (MEI) offsite. Offsite environmental surveillance data, where available, are used to confirm that calculated emissions are, indeed, conservative.

Table 2.0 Summary of Annual Air Emissions Data by Source ${ }^{(a)}$ (Multiply Ci by 37 to obtain Gbq)

\begin{tabular}{||l|l|c|c|c|c||}
\hline \hline $\begin{array}{l}\text { Point } \\
\text { Source }\end{array}$ & $\begin{array}{l}\text { Type of } \\
\text { Control }\end{array}$ & Efficiency & $\begin{array}{c}\text { Distance to } \\
\text { Nearest Receptor }\end{array}$ & \multicolumn{1}{|c||}{ Nuclide } & Quantity (Ci) \\
\hline Bldg. CP-95A Lab & None & $0 \%$ & $42 \mathrm{~km}$ & ${ }^{3} \mathrm{H}$ & $4.6 \times 10^{-5}$ \\
DAF Lab, Area 6 & None & $0 \%$ & $40 \mathrm{~km}$ & ${ }^{3} \mathrm{H}$ & 5.6 \\
Building A-1 & None & $0 \%$ & $0.1 \mathrm{~km}$ & ${ }^{3} \mathrm{H}$ & 0.37 \\
Grouped Sources & & & & & \\
Building 650 & None & $0 \%$ & $24 \mathrm{~km}$ & ${ }^{3} \mathrm{H}$ & $3.0 \times 10^{-4}$ \\
Laboratory (12) ${ }^{(\mathrm{b})}$ & & & & ${ }^{85} \mathrm{Kr}$ & $2.1 \times 10^{-6}$ \\
& & & & & $5.4 \times 10^{-7}$ \\
Area Sources & & & & & \\
Onsite & None & $0 \%$ & $20-60 \mathrm{~km}$ & ${ }^{3} \mathrm{H}^{(\mathrm{c})}$ & 426 \\
& None & $0 \%$ & $20-60 \mathrm{~km}$ & ${ }^{241} \mathrm{Am}$ & $4.7 \times 10^{-2}$ \\
Near Offsite & None & $0 \%$ & $20-60 \mathrm{~km}$ & ${ }^{239+240} \mathrm{Pu}$ & $2.9 \times 10^{-1}$ \\
& None & $0 \%$ & $38-43 \mathrm{~km}$ & ${ }^{241} \mathrm{Am}$ & $2.0 \times 10^{-3}$ \\
\hline
\end{tabular}

(a) All locations at or near the NTS except Building A-1, which is in North Las Vegas.

(b) $(x)$ is number of vents or stacks.

(c) Emissions based on environmental surveillance data, tritiated water discharged from the E Tunnel and tritiated water pumped from Well RNM-2s into the CAMBRIC ditch. 
A summary of the NTS total CY 2000 emissions for NESHAP's reporting, by radionuclide, is provided in Table 3.0.

Table 3.0 Total Emissions for CY 2000 (Multiply Ci by 37 to obtain GBq)

\begin{tabular}{||c|c|l||}
\hline Radionuclide & Half-Life $(\mathrm{yr})^{(\mathrm{a})}$ & Annual Quantity (Ci) \\
\hline${ }^{3} \mathrm{H}$ & 12.35 & 431 \\
${ }^{85} \mathrm{Kr}$ & 10.72 & $2.1 \times 10^{-6}$ \\
${ }^{129} \mathrm{I}$ & $1.57 \times 10^{7}$ & $5.4 \times 10^{-7}$ \\
${ }^{241} \mathrm{Am}$ & 432.2 & $4.9 \times 10^{-2}$ \\
${ }^{239} \mathrm{Pu}$ & 24,065 & \\
${ }^{240} \mathrm{Pu}$ & 6,537 & $3.2 \times 10^{-1}$ (combined $\left.{ }^{239+240} \mathrm{Pu}\right)$ \\
\hline
\end{tabular}

(a) Source of half-life for radionuclides (ICRP 1990).

Note: This table includes all worst-case point and diffuse source releases. 


\section{SECTION III \\ DOSE ASSESSMENTS}

\section{SUMMARY OF INPUT PARAMETERS}

CAP88-PC was used to calculate EDEs to offsite residents. The input parameters were the radionuclide releases listed in Section II above as determined from effluent monitoring performed by the contractor, evaporation of HTO, and calculations of diffuse source emissions that are based on environmental monitoring data and plutonium/americium resuspension.

The estimated release of tritium from Building A-1 at the NLVF was calculated from measurements of tritium in atmospheric moisture samples collected in the basement area in January and December 2000 and the flow rate of the air ventilated from the basement. A detailed description is given in Appendix A.

The amount of HTO evaporated from ponds was calculated from measurements of HTO concentration and water volume discharged into the containment ponds. A description of the source term estimated for this emission source is contained in Appendix B.

The releases of radioactivity from the NTS laboratories were conservatively calculated from actual inventories of radioactive gases or volatile radionuclides assuming that they were entirely released gradually over the year. Appendix $C$ provides additional details of the sources used in the calculations of EDEs to offsite residents and the results.

Several diffuse sources of tritium from past nuclear tests are located at the NTS. The annual source term of such emissions were estimated from environmental air samples collected near the sites of these sources and CAP88-PC calculations. Appendix D explains the methodology and results.

The source terms from the resuspension of americium and plutonium deposited on soil from past nuclear testing were calculated from a resuspension model (NRC 1983) and the radionuclide inventory of ground-surface contamination listed in Table 1.0 (DOE 1991; DOE 1992). Appendix $E$ describes the application of the model and the resulting emission source terms for americium and plutonium for each area are listed in Table E.1.

The source data listed in Table 2.0 are used with five stability array (STAR) data files as input to CAP88-PC. The five STARs for the NTS include the files with names NTSYUCCA, AREA05, MEDA20, DESERTRK, and T TUNNEL. NTSYUCCA is used for sources on Yucca Flat (Areas 1, 2, 3, 4, 6, 7, 8, 9, 10, and 18); AREA05 is used for sources in Area 5, which includes Frenchman Flat; DESERTRK is used for sources in Mercury; MEDA20 is used for sources in Areas 19 and 20; and T TUNNEL for the tunnel pond sources in Area 12. MEDA20, T TUNNEL, and AREA05 were developed by the Air Resources Laboratory, Special Operations and Research Division (ARL/SORD), using data obtained from the meteorological stations located near the boundary of Areas 19 and 20 on Pahute Mesa, near the tunnels in Area 12, and at Well 5B in Area 5. The other two files were provided by the National Climatic Data Center in North Carolina, based on data from meteorological stations in Yucca Flat and at Desert Rock Meteorological Observatory (DRA). The ARL/SORD assessment is attached as Appendix F. For each of these five STARs there may be a different location for the MEl; but when the contributions of all the NTS sources to a given location are considered, only one location would receive the maximum exposure. 


\section{COMPLIANCE ASSESSMENT}

The source terms from Table 2.0 and Table E.1, for the non-point sources from the resuspension of americium and plutonium, were used as input to CAP88-PC calculations in conjunction with the above mentioned wind files for the appropriate NTS areas to calculate the EDEs to all offsite residents within $80 \mathrm{~km}$ of each emission location. As shown by Table 5.0, the EDEs for each location were summed for all conservatively estimated emissions for the year. The location of the $\mathrm{MEl}$ is once again at Springdale, Nevada, where a population of approximately 20 persons each received $0.17 \mathrm{mrem} / \mathrm{yr}$, which is only 1.7 percent of the $10 \mathrm{mrem} / \mathrm{yr}$ standard of NESHAPs. Table 4.0 summarizes the contributions to the EDEs from the locations of the emissions and the radionuclide sources. As shown by this table, the diffuse tritium sources and the laboratory sources contributed little to the total dose; the resuspension of americium and plutonium from all areas contributed virtually all of the dose. Appendices A through $E$ contain the methods by which the releases of radionuclides were calculated.

Descriptions and estimations of the errors involved in each step of the process (measurement, monitoring, and calculation), estimations of potential releases, and worst-case scenarios are also included where possible. Evaporative and resuspension emissions are also compared to EPA suggested methods as a check on the relative values produced.

Table 4.0 Summary of CY 2000 CAP88-PC Calculations of EDE to the MEI Offsite, Springdale, Nevada ${ }^{(a)}$

\begin{tabular}{|c|c|c|}
\hline Source & $\begin{array}{c}\text { Distance to Individual } \\
\text { and Direction }\end{array}$ & $\begin{array}{l}\text { EDE } \\
(\text { mrem })^{(b)}\end{array}$ \\
\hline \multicolumn{3}{|l|}{ Tritium (diffuse) } \\
\hline Area 5 & $74 \mathrm{~km}$ WNW & $6.9 \times 10^{-7}$ \\
\hline Area 10 & 65 km WSW & $6.9 \times 10^{-4}$ \\
\hline Area 12 & 53 km WSW & $3.2 \times 10^{-5(c)}$ \\
\hline Area 20 & 38 km SSW & $3.6 \times 10^{-4}$ \\
\hline Subtotal & & $\overline{1.1 \times 10^{-3}}$ \\
\hline \multicolumn{3}{|l|}{ Laboratories $^{(\mathrm{d})}$} \\
\hline Area 6 & 64 km WNW & $6.4 \times 10^{-6}$ \\
\hline Area 23 & 78 km WNW & $\underline{4.0 \times 10^{-6}}$ \\
\hline Subtotal & & $1.0 \times 10^{-5}$ \\
\hline \multicolumn{3}{|l|}{ Resuspension } \\
\hline Area 3 & $62 \mathrm{~km} \mathrm{~W}$ & $5.7 \times 10^{-3}$ \\
\hline Area 5 & 74 km WNW & $1.9 \times 10^{-4}$ \\
\hline Area 8 & 62 km WSW & $1.8 \times 10^{-2}$ \\
\hline Area 9 & 64 km W & $1.2 \times 10^{-2}$ \\
\hline Area 10 & $65 \mathrm{~km}$ WSW & $1.7 \times 10^{-2}$ \\
\hline Areas 18/19/20 & 42 km SW & $7.7 \times 10^{-2}$ \\
\hline All Other Areas & & $\underline{4.2 \times 10^{-2}}$ \\
\hline Subtotal & -- & $1.7 \times 10^{-1}$ \\
\hline TOTAL EDE & & 0.17 mrem \\
\hline
\end{tabular}

(a) Location of residences and communities around the NTS are shown in Figure 1.0.

(b) For mSv, multiply by $10^{-2}$.

(c) Assumes evaporation of all tritiated water influents to ponds.

(d) Assumes that all of the gaseous and volatile sources were emitted during the year. 
Beginning in July 1999, high volume air particulate samplers $\left(68 \mathrm{~m}^{3} / \mathrm{h}\right)$ were operated by Bechtel Nevada at Alamo, Amargosa Center, Beatty, Goldfield, Indian Springs, and Rachel for the purpose of validating the EDEs listed for these locations in Table 5.0, which were calculated by CAP88-PC. In September 2000, sampling at these locations was terminated. The weekly samples from these locations were composited monthly and analyzed for americium and plutonium. Table 6.0 compares the EDEs calculated by CAP88-PC with the EDEs calculated from the analytical results for the air filters. As shown by this table, the EDEs calculated by CAP88-PC were consistently higher than the EDEs calculated from the air sampling results, except for Alamo. The CAP88-PC EDE at Alamo was lower than the EDE calculated from air sampling results due to the fact that most of the sources on the NTS were beyond $80 \mathrm{~km}$, which is the maximum distance for CAP88-PC calculations. 
Table 5.0 Calculated EDEs ( $\mu$ rem)

\begin{tabular}{|c|c|c|c|c|c|c|c|c|c|c|c|c|c|c|}
\hline \multirow[b]{3}{*}{ Location } & \multicolumn{14}{|c|}{ EDE ( $\mu \mathrm{rem} / \mathrm{yr})$ due to emissions from: } \\
\hline & \multicolumn{11}{|c|}{${ }^{239+240} \mathrm{Pu}$ and ${ }^{241} \mathrm{Am}$} & \multicolumn{3}{|c|}{ (Tritium) } \\
\hline & Area 1 & Area 2 & Area 3 & Area 4 & Area 5 & Area 6 & Area 7 & Area 8 & Area 9 & Area 10 & Area 11 & Area 5 & Area 6 & Area 10 \\
\hline ALAMO & & & & & & & & & & 3.9 & & & & 0.24 \\
\hline AMARGOSA VALLEY & 3 & 3.1 & 4.6 & 6.6 & 0.38 & 1.2 & 1.8 & 15 & 11 & 14 & 3.5 & 0.0013 & 0.012 & 0.52 \\
\hline ASH MEADOWS & 3.3 & & 4.8 & & 0.3 & 1.3 & & & & & 3.9 & 0.0011 & 0.012 & \\
\hline BEATTY & 4 & 3.3 & 5.4 & 6.6 & 0.23 & 1.3 & 2.1 & 15 & 10 & 15 & 3.6 & 0.0011 & 0.011 & 0.63 \\
\hline CACTUS SPRINGS & 1.2 & 1.3 & 3.8 & 1.8 & 1.3 & 1.1 & 1.2 & 6.7 & 5.3 & 7.4 & 3.7 & 0.46 & 0.007 & 0.51 \\
\hline \multicolumn{15}{|l|}{ CLARK STATION } \\
\hline CORN CREEK STA. & & & & & 0.34 & & & & & & 0.91 & 0.0006 & & \\
\hline CRYSTAL & 3.2 & 2.3 & 6.7 & 4.9 & 0.82 & 2.2 & 1.8 & 11 & 8.3 & 11 & 6.7 & 0.0019 & 0.016 & 0.43 \\
\hline DEATH VALLEY JCT. & & & & & 0.22 & & & & & & & 0.0012 & 0.011 & \\
\hline \multicolumn{15}{|l|}{ FURNACE CREEK } \\
\hline \multicolumn{15}{|l|}{ GOLDFIELD } \\
\hline \multicolumn{15}{|l|}{ HIKO } \\
\hline INDIAN SPRINGS & 1.1 & 1.3 & 3 & 1.8 & 1.3 & 0.64 & 1.2 & 6.6 & 5.3 & 6.9 & 3.8 & 0.0087 & 0.0066 & 0.5 \\
\hline LATHROP WELLS & 6.9 & 4 & 7.6 & 10 & 0.71 & 2.2 & 2.9 & 19 & 14 & 19 & 5.8 & 0.002 & 0.015 & 0.6 \\
\hline \multicolumn{15}{|l|}{ LIDA JCT. } \\
\hline MEDLIN'S RANCH & 1.6 & 1.3 & 2.9 & 3.1 & & 0.56 & & 7.8 & 7.1 & 8.6 & 2 & 0.0006 & 0.0055 & 0.31 \\
\hline MT. CHARLESTON & & & & & 0.28 & & & & & & & 0.0011 & 0.009 & \\
\hline PAHRUMP & & & & & 0.33 & & & & & & & 0.001 & 0.0083 & \\
\hline PENOYER FARMS & 1.5 & 1.5 & 2.3 & 2.7 & & 0.43 & 1.1 & 10 & 5.7 & 10 & 1.3 & & & 0.31 \\
\hline PRISON COMPLEX & & & 1.5 & 2.6 & 0.83 & 0.4 & & & & & 1.3 & 0.0008 & 0.0059 & \\
\hline RACHEL & 1.4 & 1.4 & 2.2 & & & 0.46 & 1 & 8.3 & 5.4 & 9.5 & 1.5 & & & 0.3 \\
\hline SARCOBATUS FLATS & 1.1 & 2.8 & & 5.3 & & & & 14 & 8.8 & 13 & & & & 0.47 \\
\hline \multicolumn{15}{|l|}{ SCOTTY'S JCT. } \\
\hline \multicolumn{15}{|l|}{ SCOTTY'S CASTLE } \\
\hline SPRINGDALE & 4.9 & 4.8 & 5.7 & 8.3 & 0.19 & 1.3 & 2.3 & 18 & 12 & 17 & 3.6 & 0.0007 & 0.0064 & 0.69 \\
\hline STATE LINE & & & & & 0.24 & 1.2 & & & & & 3.5 & 0.0012 & 0.011 & \\
\hline \multicolumn{15}{|l|}{ STONE CABIN RANCH } \\
\hline TOLICHA PEAK & 1.7 & 1.6 & 2.1 & 6.4 & & 0.5 & 0.97 & 17 & & 16 & & & 0.0058 & 0.53 \\
\hline \multicolumn{15}{|l|}{ TONOPAH } \\
\hline \multicolumn{15}{|l|}{ TWIN SPRINGS RN } \\
\hline U.S. ECOLOGY & 4.2 & 2.8 & 5.5 & 6.6 & 0.26 & 1.4 & 2.2 & 13 & 5.1 & 13 & 3.8 & 0.0012 & 0.014 & 0.56 \\
\hline
\end{tabular}


Table 5.0 (Calculated EDEs [ $\mu \mathrm{rem}]$, cont.)

\begin{tabular}{|c|c|c|c|c|c|c|c|c|c|c|c|c|c|}
\hline \multirow[b]{3}{*}{ Location } & \multicolumn{13}{|c|}{ EDE ( $\mu \mathrm{rem} / \mathrm{yr})$ due to emissions from: } \\
\hline & \multicolumn{10}{|c|}{${ }^{239+240} \mathrm{Pu}$ and ${ }^{241} \mathrm{Am}$} & \multicolumn{2}{|c|}{ (Tritium) } & \multirow{2}{*}{$\begin{array}{c}\text { (Lab Srcs) } \\
\text { Area } 23\end{array}$} \\
\hline & Area 12 & Area 13 & Area 15 & Area 16 & Area 17 & Area 18 & Area 19 & Area 20 & Area 30 & TTR & Area 12 & Area 20 & \\
\hline ALAMO & & 2.1 & 1.3 & & & & & & & & & & \\
\hline AMARGOSA VALLEY & 0.83 & & 1.4 & 0.9 & 2.8 & 10 & & & 2.3 & & 0.033 & 0.22 & 0.012 \\
\hline ASH MEADOWS & & & & 0.42 & & & & & 1.2 & & & & 0.011 \\
\hline BEATTY & 1 & & 0.94 & 1 & 3.9 & 24 & 18 & 9 & 4.7 & & 0.034 & 0.28 & 0.005 \\
\hline CACTUS SPRINGS & & & 16 & 0.18 & 0.73 & & & & & & & & \\
\hline CLARK STATION & & & & & & & & & & 5.6 & & & \\
\hline \multicolumn{14}{|l|}{ CORN CREEK STA. } \\
\hline CRYSTAL & 2.8 & & 5.9 & 0.67 & 2 & 4.9 & & & 1 & & 0.053 & & 0.025 \\
\hline DEATH VALLEY JCT. & & & & & & & & & 1 & & & & 0.0076 \\
\hline FURNACE CREEK & & & & & & & & & & & & & 0.0058 \\
\hline GOLDFIELD & & & & & & & & & & 6.2 & & 0.37 & \\
\hline HIKO & & 1.2 & & & & & & & & & & & \\
\hline INDIAN SPRINGS & & & 16 & 0.18 & 0.67 & & & & 0.41 & & & & 0.0099 \\
\hline LATHROP WELLS & 1 & & 1.9 & 1.4 & 4.3 & 14 & 11 & 4.4 & 3 & & 0.062 & & 0.0093 \\
\hline LIDA JCT. & & & & & & & & 3 & & 6.2 & & 0.37 & \\
\hline MEDLIN'S RANCH & 1.4 & 3.9 & 2.9 & 0.22 & 0.83 & 2.6 & 3.9 & & & & 0.037 & & \\
\hline MT. CHARLESTON & & & & & & & & & & & & & 0.0048 \\
\hline PAHRUMP & & & & & & & & & & & & & 0.0043 \\
\hline PENOYER FARMS & 2.3 & 11 & 2.7 & 0.21 & 1.2 & 4.8 & 9.7 & 1.7 & & 3.1 & 0.036 & 0.2 & \\
\hline PRISON COMPLEX & & & & 0.14 & & & & & & & & & 0.007 \\
\hline RACHEL & 1.2 & 4.6 & 2.6 & 0.2 & 1.1 & 4.4 & 7.5 & 1.5 & & 2.6 & 0.035 & 0.2 & \\
\hline SARCOBATUS FLATS & 0.63 & & & 0.26 & 2.6 & 8.3 & 11 & 20 & 1.2 & 4.1 & 0.05 & 0.49 & \\
\hline SCOTTY'S JCT. & 1.1 & & & & & 4.3 & 6.8 & 7.2 & 0.61 & 5 & 0.045 & 0.41 & \\
\hline SCOTTY'S CASTLE & & & & & & & & 6.6 & & & & & \\
\hline SPRINGDALE & 1.1 & 0.62 & 2.5 & 0.98 & 4.9 & 32 & 30 & 15 & 2.6 & 2.7 & 0.032 & 0.36 & 0.004 \\
\hline STATELINE & & & & 0.56 & & & & & 1.2 & & & & 0.0087 \\
\hline STONE CABIN RANCH & & & & & & & & & & 4.4 & & & \\
\hline TOLICHA PEAK & 3 & 1.4 & 3 & 0.3 & 1.7 & 12 & 18 & 24 & 2.7 & 6.3 & 0.06 & 0.83 & \\
\hline TONOPAH & & & & & & & & & & 3.7 & & & \\
\hline TWIN SPRINGS RN & & & & & & & & & & 5.6 & & & \\
\hline U.S. ECOLOGY & 0.96 & & 0.96 & 1.1 & 3.1 & 22 & 14 & 6.5 & 4.4 & & 0.033 & 0.25 & 0.0053 \\
\hline
\end{tabular}


Table 5.0 (Calculated EDEs [ $\mu \mathrm{rem}]$, cont.)

\begin{tabular}{|c|c|c|c|}
\hline \multirow[b]{2}{*}{ Location } & \multicolumn{3}{|c|}{ Summary } \\
\hline & $\begin{array}{l}\text { EDE Sum } \\
(\mu \mathrm{rem} / \mathrm{yr})\end{array}$ & Population & $\begin{array}{l}\text { Collective } \\
\text { EDE } \\
\text { (person-mrem) }\end{array}$ \\
\hline ALAMO & 7.5 & 507 & 3.8 \\
\hline AMARGOSA VALLEY & 83.2 & 1129 & 93.9 \\
\hline ASH MEADOWS & 15.2 & 10 & 0.15 \\
\hline BEATTY & 130.0 & 1482 & 193. \\
\hline CACTUS SPRINGS & 52.6 & 10 & 0.527 \\
\hline CLARK STATION & 5.6 & & 0 \\
\hline CORN CREEK STA. & 1.2 & 4 & 0.005 \\
\hline CRYSTAL & 76.7 & 45 & 3.45 \\
\hline DEATH VALLEY JCT. & 1.2 & 7 & 0.0086 \\
\hline FURNACE CREEK & 0.0058 & 50 & 0.00029 \\
\hline GOLDFIELD & 6.5 & 574 & 3.77 \\
\hline HIKO & 1.2 & 103 & 0.123 \\
\hline INDIAN SPRINGS & 50.7 & 1387 & 70.3 \\
\hline LATHROP WELLS & 133.7 & 30 & 4.01 \\
\hline LIDA JCT. & 9.5 & 8 & 0.076 \\
\hline MEDLIN'S RANCH & 51.0 & 2 & 0.102 \\
\hline
\end{tabular}

\begin{tabular}{||l||}
\multicolumn{1}{c||}{ Location } \\
\hline MT. CHARLESTON \\
\hline PAHRUMP \\
\hline PENOYER FARMS \\
\hline PRISON COMPLEX \\
\hline RACHEL \\
\hline SARCOBATUS FLATS \\
\hline SCOTTY'S JCT. \\
\hline SCOTTY'S CASTLE \\
\hline SPRINGDALE \\
\hline STATELINE \\
\hline STONE CABIN RANCH \\
\hline TOLICHA PEAK \\
\hline TONOPAH \\
\hline TWIN SPRINGS RN \\
\hline U.S. ECOLOGY \\
\hline
\end{tabular}

\begin{tabular}{||c|c|c||}
\hline \multicolumn{3}{||c||}{ Summary } \\
\hline $\begin{array}{c}\text { EDE Sum } \\
(\mu \mathrm{rem} / \mathbf{y r})\end{array}$ & Population $^{(\mathbf{a})}$ & $\begin{array}{c}\text { Collective } \\
\text { EDE } \\
\text { (person-mrem) }\end{array}$ \\
\hline 0.2 & 917 & 0.2 \\
\hline 0.3 & 25450 & 8.3 \\
\hline 73.7 & 16 & 1.1 \\
\hline 6.7 & 3199 & 21.7 \\
\hline 57.3 & 105 & 6.0 \\
\hline 94.1 & 40 & 3.7 \\
\hline 25.4 & 10 & 0.2 \\
\hline 6.6 & 15 & 0.09 \\
\hline 171. & 20 & 3.4 \\
\hline 6.7 & 70 & 0.4 \\
\hline 4.4 & 6 & 0.02 \\
\hline 120. & 10 & 1.2 \\
\hline 3.7 & 3134 & 11.5 \\
\hline 5.6 & 6 & 0.03 \\
\hline 111. & 35 & 3.9 \\
\hline SUM & 38381 & 435. \\
\hline \hline
\end{tabular}

Total Population: 38,381

EDE to MEl: 0.17 mrem MEI Location: Springdale, NV

Maximum Individual Dose Calculated from Following Sources - mrem

\begin{tabular}{||c||c|c|}
\hline \hline Tritium & Laboratory Sources & ${ }^{239+240} \mathrm{Pu}$ and ${ }^{241} \mathrm{Am}$ \\
\hline \hline 0.0011 & 0.025 & 0.17 \\
\hline
\end{tabular}

Total Person-rem: 0.44 $+2$

(a) Population of incorporated towns estimated by Nevada State Demographer (Hardcastle 2000) 
Table 6.0 Comparison of EDEs Calculated by CAP88-PC with EDEs Calculated from Measured ${ }^{241} \mathrm{Am}$ and ${ }^{239+240} \mathrm{Pu}$ Concentrations in Air

\begin{tabular}{||l|c|c|c|c|c|c||}
\hline \multirow{2}{*}{ Location } & \multicolumn{2}{|c|}{} & \multicolumn{2}{c|}{$\begin{array}{c}\text { Avg. Conc. from Air } \\
\text { Sampling }\end{array}$} & $\begin{array}{c}\text { EDE from } \\
\text { CAP88 }\end{array}$ & $\begin{array}{c}\text { EDE from Air } \\
\text { Sampling }^{(\mathrm{c})}\end{array}$ \\
\cline { 2 - 7 } & ${ }^{239,240} \mathrm{Pu}$ & ${ }^{241} \mathrm{Am}$ & ${ }^{239,240} \mathrm{Pu}, \mathrm{pCi} / \mathrm{m}$ & ${ }^{241} \mathrm{Am}, \mathrm{pCi} / \mathrm{m}^{3}$ & $(\mu \mathrm{rem})$ & $(\mu \mathrm{rem})$ \\
\hline Alamo & $9 / 6$ & $5 / 0$ & $7.50 \mathrm{E}-06$ & $2.01 \mathrm{E}-07$ & $7.5^{(\mathrm{d})}$ & 21.7 \\
Amargosa & $9 / 7$ & $7 / 1$ & $2.48 \mathrm{E}-05$ & $2.11 \mathrm{E}-06$ & 83. & 77.9 \\
Beatty & $9 / 7$ & $6 / 2$ & $2.00 \mathrm{E}-06$ & $4.65 \mathrm{E}-07$ & 130. & 7.6 \\
Goldfield & $9 / 5$ & $6 / 0$ & $1.05 \mathrm{E}-06$ & $1.43 \mathrm{E}-07$ & 6.6 & 3.5 \\
Indian Springs & $9 / 6$ & $7 / 0$ & $2.83 \mathrm{E}-06$ & $2.27 \mathrm{E}-07$ & 51. & 8.8 \\
Rachel & $9 / 6$ & $6 / 0$ & $9.90 \mathrm{E}-06$ & $5.43 \mathrm{E}-07$ & 57. & 29.8 \\
\hline Average & \multicolumn{7}{|l}{} & 56 & 25 \\
\hline \hline
\end{tabular}

(a) 9/6 represents nine analytical results out of which six were above their MDC.

(b) Measured concentrations were assumed to be from NTS airborne emissions; however, it was not possible to verify this.

(c) EDE from ${ }^{241} \mathrm{Am}$ and ${ }^{239+240} \mathrm{Pu}$ calculated from an assumed annual breathing rate of $8400 \mathrm{~m}^{3} / \mathrm{yr}$, and the respective dose factors of $520 \mathrm{rem} / \mu \mathrm{Ci}$ and $330 \mathrm{rem} / \mu \mathrm{Ci}$. Although the concentration averages were determined over 9 months, they were assumed to be representative for all 12 months of the year.

(d) Estimate low due to most of NTS sources being beyond $80 \mathrm{~km}$, which is the maximum range for CAP88-PC calculations. 
This page intentionally left blank 


\section{CERTIFICATION}

I certify under penalty of law that I have personally examined and am familiar with the information submitted herein and based on my inquiry of those individuals immediately responsible for obtaining the information, I believe that the submitted information is true, accurate and complete. I am aware that there are significant penalties for submitting false information including the possibility of fine and imprisonment. See 18 U.S.C. 1001.

Name: Kathleen A. Carlson, Manager, NNSA/NV

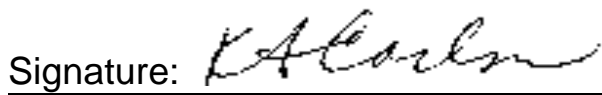

Date: $6 / 26 / \% 1$ 
This page intentionally left blank 


\section{SECTION IV \\ ADDITIONAL INFORMATION}

\section{NEW CONSTRUCTION/MODIFICATION ACTIVITIES AT THE NTS}

Plans and construction of a hydrogen gas gun in Building 5100 in Area 27 continued during the year with a target completion date of October 1, 2001. Experiments with the two-stage light gas gun will be conducted under the Joint Actinide Shock Physics Experimental Research (Project JASPER) Facility using plutonium as target material. Approval by EPA has been obtained for the project and a stack monitoring system was installed to assure that the experimental emissions are in conformance with NESHAPs once operations begin.

In conjunction with Project JASPER, plans for the construction of two glove boxes in Building 341, Device Assembly Facility (DAF), in Area 6 were finalized so that the construction will be completed at the same time as the gas gun. The targets used in the gas gun are prepared for the experiments in the glove boxes. Based upon an assessment of the potential emissions of plutonium that could occur from the glove boxes, application to or approval from the EPA was not necessary because the EDE to the MEI was less than $0.1 \mathrm{mrem} / \mathrm{year}$ (only $1.2 \times 10^{-7} \mu \mathrm{rem} /$ year at Lathrop Wells, Nevada, $42 \mathrm{~km}$ southwest of the DAF). Details of this assessment are given in Appendix G.

\section{UNPLANNED RELEASES DURING CALENDAR YEAR (CY) 2000}

No unplanned release occurred on the NTS during CY 2000. There was a detectable non-NTS release, at the Atlas Facility, located in North Las Vegas, that was a continuance of a 1995 incident (see Appendix A for a description).

\section{SOURCES OF DIFFUSE OR FUGITIVE EMISSIONS}

This year these sources included the following:

- Evaporation from containment ponds that receive liquid effluents from E Tunnel in Area 12.

- Evaporation of water discharged from Well RMN-2s into the CAMBRIC ditch for Project Osprey.

- Resuspension of ${ }^{241} \mathrm{Am}$ and ${ }^{239+240} \mathrm{Pu}$ from soil deposits on the NTS areas shown by Table 1.0.

- Seepage of tritium from the SEDAN and SCHOONER craters.

- Low-level waste packages buried at the RWMS-5.

The EDE to the MEI was principally due to the diffuse sources. The EDE from point sources was negligible. The methods used to determine the emissions from these diffuse sources are described in the appendices. 
This page intentionally left blank 
FIGURES 
This page intentionally left blank 


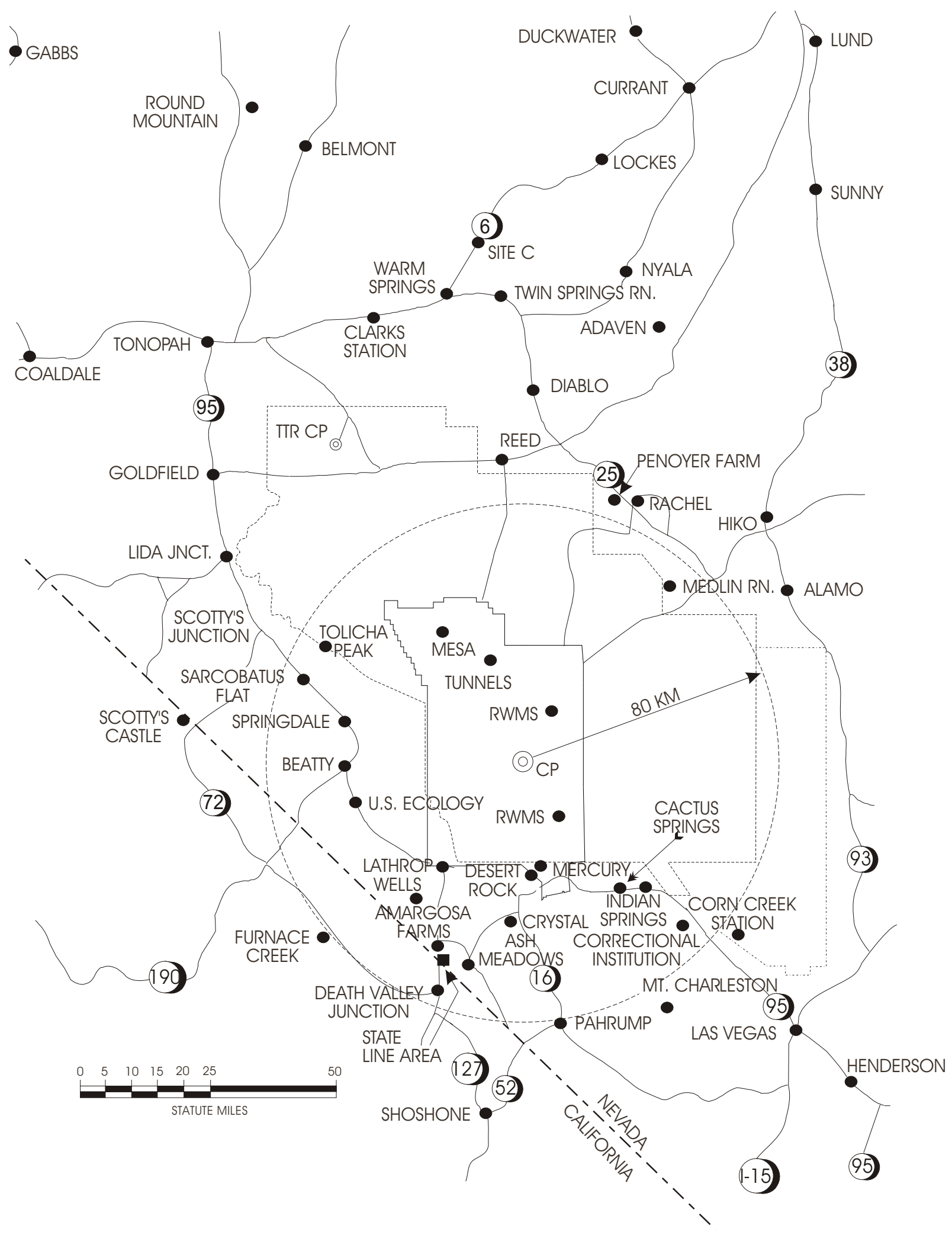

Figure 1.0 Map of the NTS and Surrounding Areas 


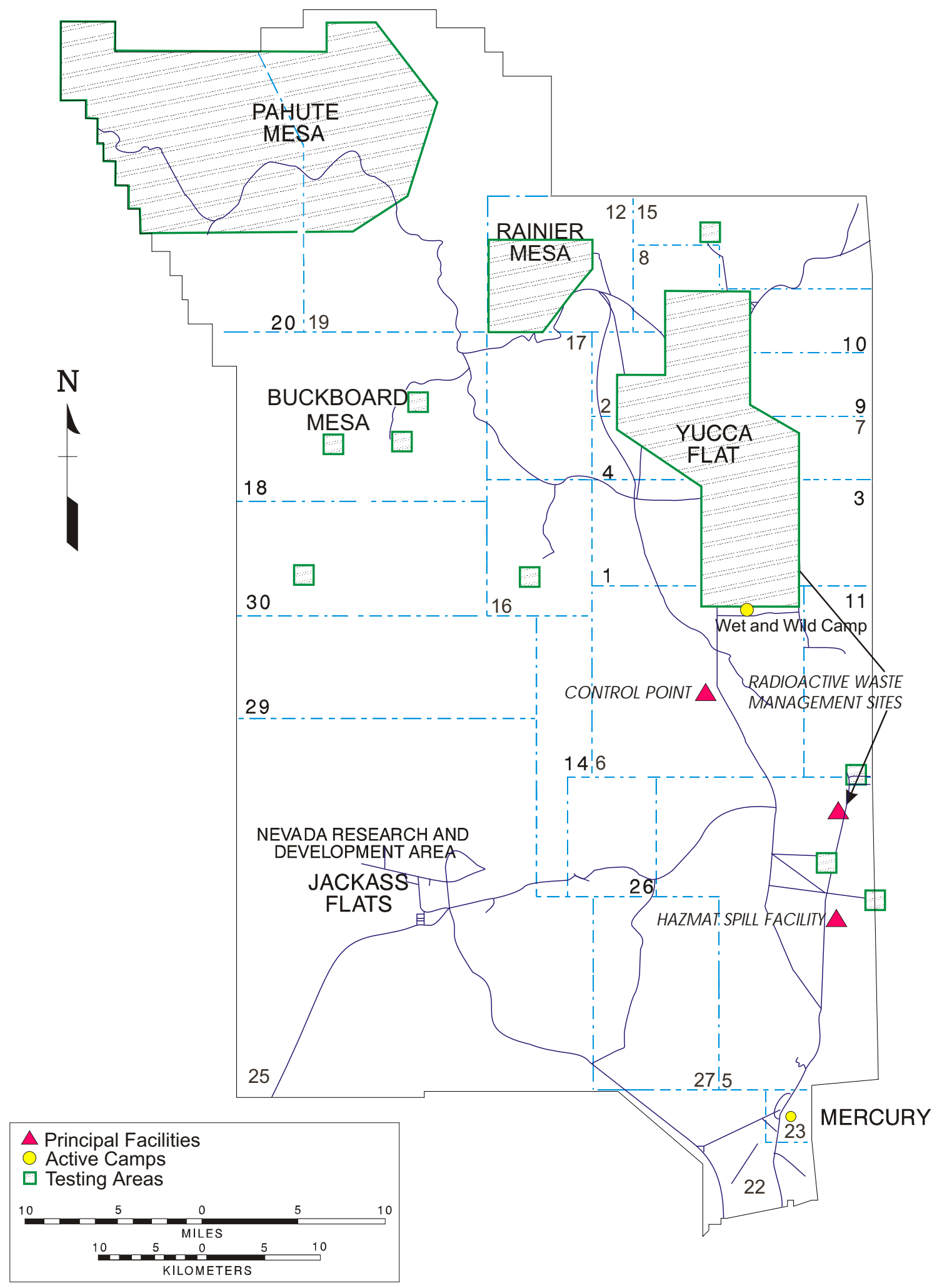

Figure 2.0 Nuclear Testing Areas on the NTS 


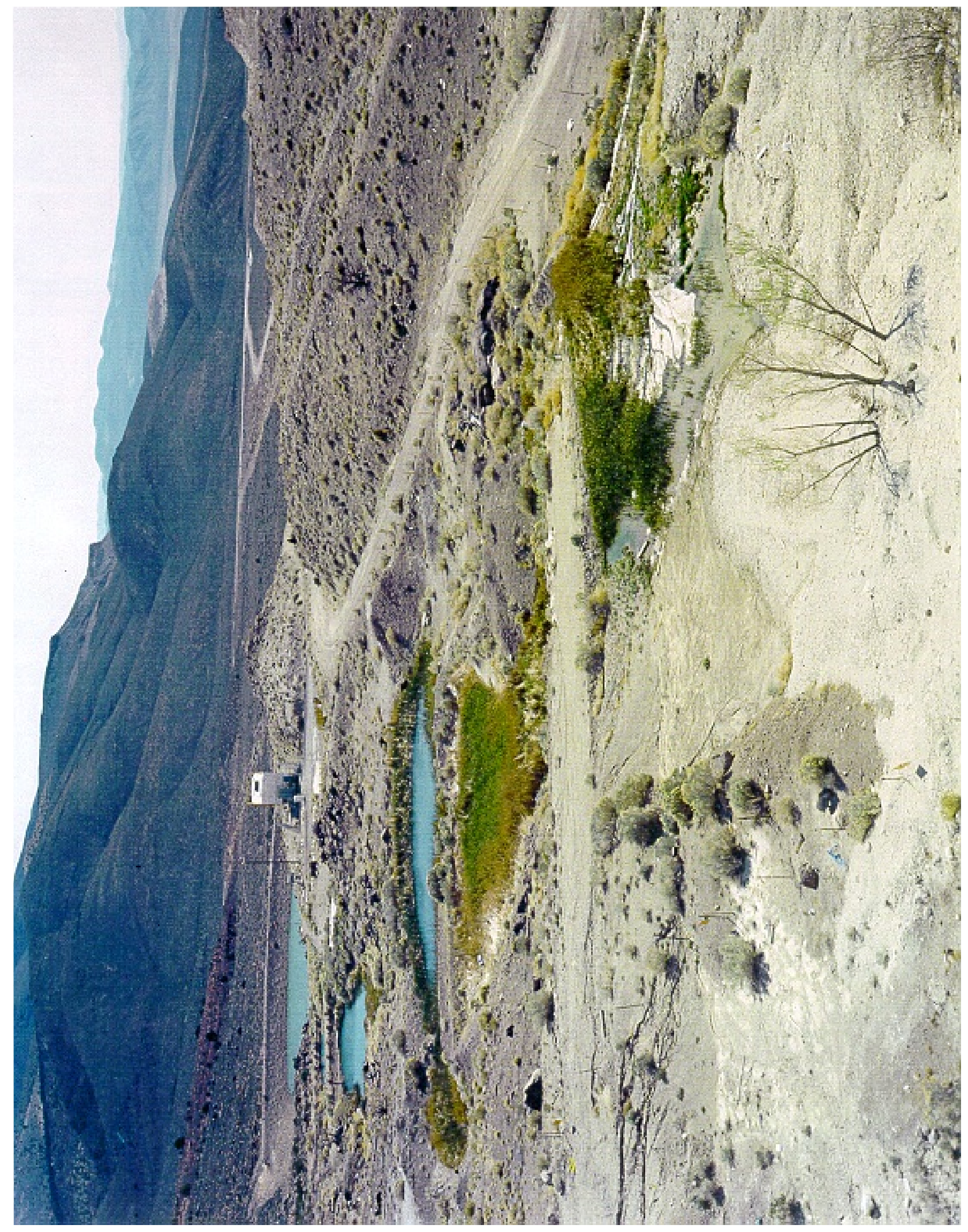

Figure 3.0 Photograph of Tunnel Containment Ponds (Photo Date Not Available) 


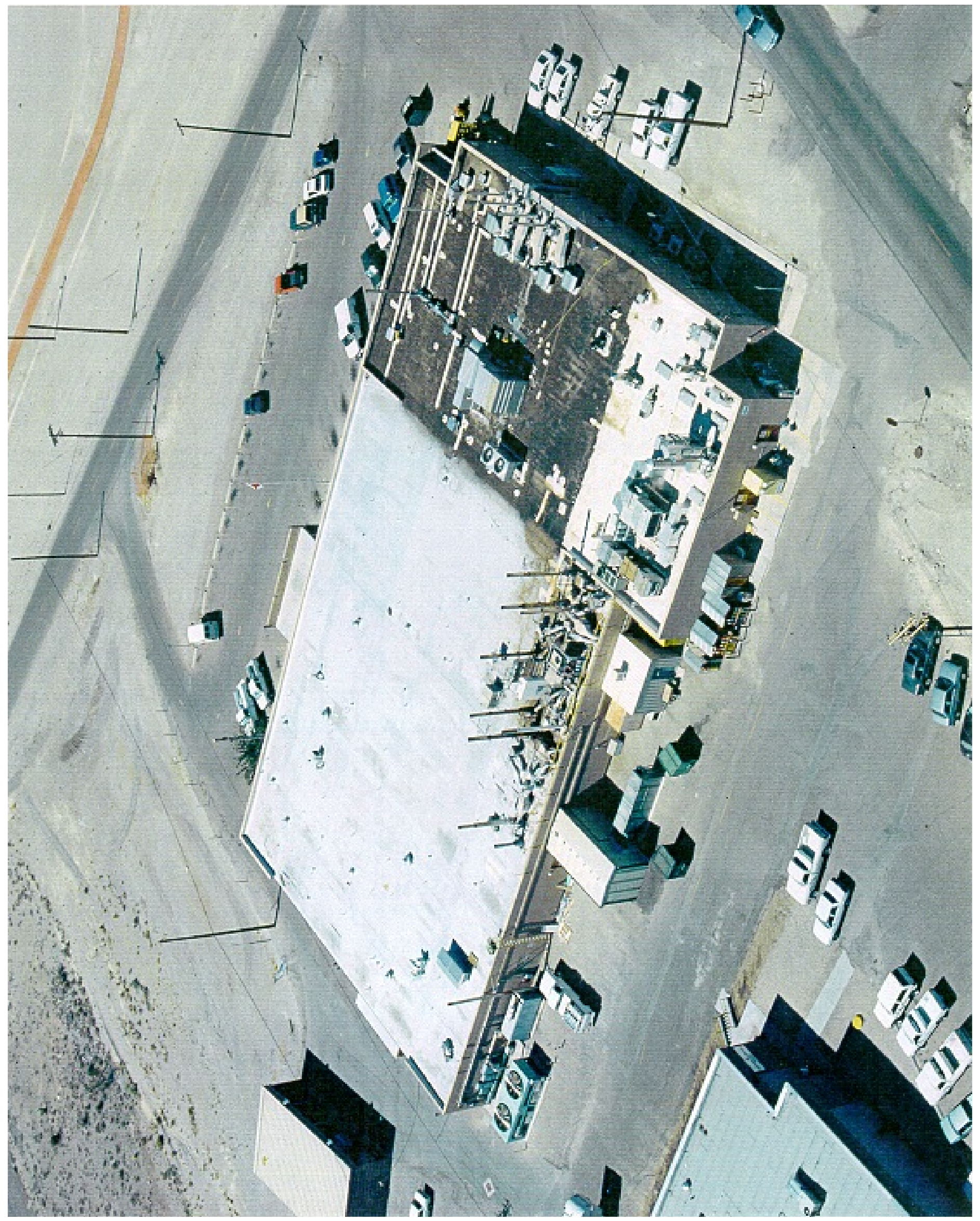

Figure 4.0 Photograph of the Building 650 Hood Ventilation Stacks Seen from Above (Photo Date Not Available) 


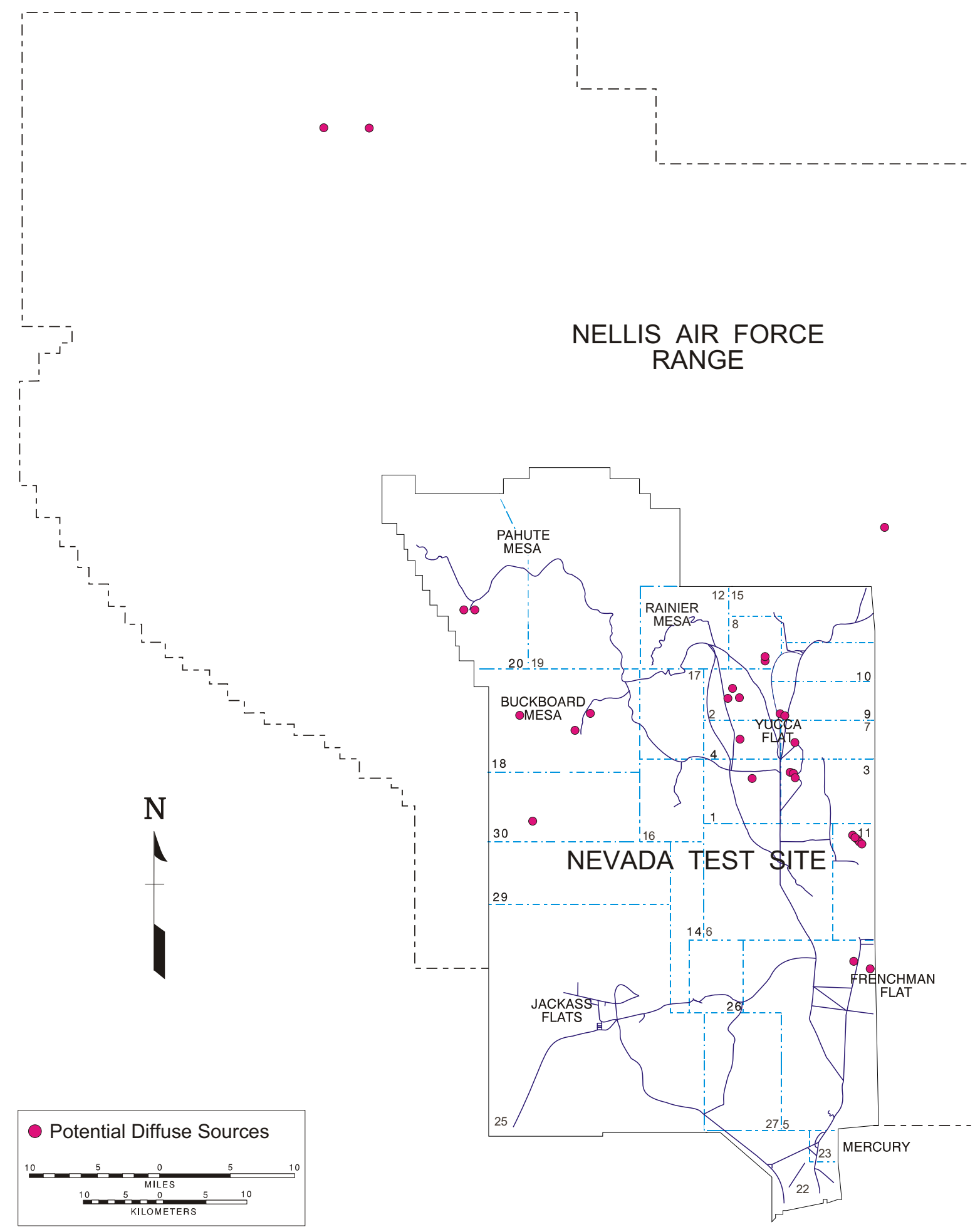

Figure 5.0 Locations of Potential Diffuse Sources of Plutonium on and Near the NTS 
This page intentionally left blank 
APPENDICES 
This page intentionally left blank 


\section{APPENDIX A}

\section{PUBLIC DOSE CALCULATIONS FOR THE ATLAS TRITIUM INCIDENT}

\section{ENVIRONMENTAL SURVEILLANCE}

As reported in the 1995 NESHAPs report (DOE 1996b), a container of tritium foils was opened in the Atlas Facility at the North Las Vegas Operations area that emitted about $1 \mathrm{Ci}$ of ${ }^{3} \mathrm{H}$ into a basement area used as a fixed radiation source range. Environmental surveillance began with notification on Friday, July 14, 1995, that the tritium leak had occurred. Environmental HTO samplers were installed at three locations outside the facility. Later, an HTO sampler was installed in the basement so that progress on cleanup of the spill could be monitored. After cleanup began, the environmental samplers were removed, but the basement air sampler continued operation through January 5, 1998, at which time, only two-week samples were collected each quarter. The 1996, 1997, and 1998 results and offsite EDEs were reported in the respective annual NESHAPs reports.

This year two tritiated atmospheric moisture samples were collected in the Building A-1 basement. The results are as follows:

Location

Building A-1, Rm. 4862

Average
Collection Period

$02 / 02 / 2000$ to $02 / 09 / 2000$

$12 / 14 / 2000$ to $12 / 28 / 2000$
Tritium Conc. $\left(\mathrm{pCi} / \mathrm{m}^{3}\right)$

52,800

20,300

From the average tritium concentration for room 4862, the EDE for a hypothetical MEI (100 m northwest of the exhaust vent as determined from the 1995 NESHAPS evaluation) was calculated by the following method:

- The volume rate of air discharged to the atmosphere from the Building A-1 basement (673 cfm) during 2000 was calculated from information obtained from an industrial hygiene ventilation survey conducted on October 22, 1998. According to industrial hygiene personnel, no changes in the ventilation system have been made since then.

- The total tritium discharged was calculated by multiplying the average tritium concentration above by the air volume discharge rate and the number of minutes per year $\left(36,600 \mathrm{pCi} / \mathrm{m}^{3} \mathrm{x}\right.$ $\left.673 \mathrm{ft}^{3} / \mathrm{min} \times 0.02832 \mathrm{~m}^{3} / \mathrm{ft}^{3} \times 5.26 \times 10^{5} \mathrm{~min} / \mathrm{yr} \times 10^{-9} \mathrm{mCi} / \mathrm{pCi}\right)$ to get $370 \mathrm{mCi} / \mathrm{yr}$.

- The EDE for the MEI at the northern facility fence was calculated by multiplying the estimated total annual discharge of tritium by the CAP88-PC dose factor for that location. The resulting EDE is $(370 \mathrm{mCi} / \mathrm{yr})\left(4.8 \times 10^{-6} \mathrm{mrem} / \mathrm{mCi} / \mathrm{yr}\right)(1000 \mu \mathrm{rem} / \mathrm{mrem})$ or $1.8 \mu \mathrm{rem}$.

For comparison, the NESHAPs specifies a limit of 10 mrem to the MEI, which is a factor of 5600 greater than the calculated EDE. 
This page intentionally left blank 


\section{APPENDIX B}

\section{EMISSIONS FROM CONTAINMENT PONDS}

\section{EMISSION FROM TUNNELS, PONDS, ETC.}

Effluent water from the Area $12 \mathrm{E}$ Tunnel and any containment ponds receiving that water were sampled quarterly. During 2000, these water samples were analyzed for tritium (as HTO). The flow rate of water discharged from the tunnels was measured monthly. The total amount of radioactive liquid effluent from the tunnels was calculated from the concentration of radionuclides in the water and the total volume of water discharged during the year, based on the monthly flowrate measurements. This is a conservative estimate, as no allowance for infiltration into the soil column was made.

In order to calculate doses using CAP88-PC, an airborne source term must be known. By assuming that the total amount of tritium (as HTO) measured in the liquid effluent during the year evaporates and becomes airborne, a conservative estimate of the airborne source term is obtained. It is unlikely that this is a true source term for the containment pond, but it is an upper limit of the effluents which could be released. Despite efforts to seal it, E Tunnel is still a source of HTO to the tunnel ponds. This year it was estimated that 15 curies of HTO were discharged into the ponds.

From the estimated tritium discharged from E Tunnel, the EDE to the MEI was calculated with CAP88-PC software. The MEI for the Area 12 emission was found to reside in Lathrop Wells, Nevada, where the individual would have received an EDE of $6.2 \times 10^{-5} \mathrm{mrem}\left(6.2 \times 10^{-7} \mathrm{mSv}\right)$.

The reason for not using EPA's recommended evaporation calculation is as follows explained below.

\section{EVAPORATION OF WATER - EPA'S RECOMMENDATION}

A calculation was performed in the 1995 NESHAPs report (DOE 1996b) to estimate tritium emission from the E Tunnel pond during 1994, using the 1992 EPA methods for estimating diffuse emissions. It was concluded that the EPA's methods seriously underestimated the effluent source term; therefore, the calculation was not repeated. For reference, the equation used for that calculation is repeated below.

$$
E=\frac{20.73 \times P_{s} \times A^{0.9} \times U^{0.8}}{T^{1.47}}
$$

where $\quad \begin{array}{rlrl}\mathrm{E} & =\text { evaporation rate }, \mathrm{g} / \mathrm{s} & \mathrm{P}_{\mathrm{s}}= & \text { equilibrium water vapor pressure at } \\ \mathrm{A} & =\text { surface area of pond }, \mathrm{m}^{2} & & \text { ambient temperature, } \mathrm{mm} \mathrm{Hg} \\ \mathrm{U}=\text { wind speed }, \mathrm{m} / \mathrm{s} & \mathrm{T}={ }^{\mathrm{O}} \mathrm{K}={ }^{\circ} \mathrm{C}+273.2\end{array}$

Use of the equation resulted in a source term of $2.4 \mathrm{Ci}$ for 1995 when total evaporation would yield a more conservative source term estimate of $260 \mathrm{Ci}$. 
This page intentionally left blank 


\section{APPENDIX C}

\section{POTENTIAL RADIONUCLIDE EMISSIONS FROM RADIOANALYTICAL LABORATORIES}

\section{Analytical Services Laboratory (ASL)}

The inventory of radionuclides in the ASL of BN, located in Building 650 at the NTS, was estimated by inventorying the standards, check sources, and tracer solutions. The activity contained in these sources was orders of magnitude above that contained in samples (based on data collected in previous years).

From the inventory, only three of the items are volatile and may become a source of air emissions. These are ${ }^{3} \mathrm{H}$ (as HTO), ${ }^{129} \mathrm{I}$, and ${ }^{85} \mathrm{Kr}$ and are in the following quantities:
${ }^{3} \mathrm{H}$
${ }^{85} \mathrm{Kr}$
129
$3.0 \times 10^{-4} \mathrm{Ci}$
$2.1 \times 10^{-6} \mathrm{Ci}$
$5.4 \times 10^{-7} \mathrm{Ci}$

All of the standards and solutions were less than the possession limits set forth in Title 40 CFR 61 Appendix E.

\section{Los Alamos National Laboratory}

In previous years, this laboratory maintained standards of radioactivity containing ${ }^{133} \mathrm{Xe},{ }^{131} \mathrm{I}$, and ${ }^{3} \mathrm{H}$. Due to the test moratorium that began in 1992, the need for standards was reduced and the only standard of significance for airborne emission maintained in 2000 was $46 \mu \mathrm{Ci}$ of tritium.

\section{Device Assembly Facility (DAF) Laboratory}

The DAF laboratory is located at the NTS in Building 301, room 103. It contains about 5.6 Ci of ${ }^{3} \mathrm{H}$ in gaseous form as $\mathrm{HTO}$ and an insignificant amount in liquid form.

\section{Source Term}

The source term for these laboratories is calculated by assuming that all of the volatile substances are completely released over the course of the year to become an airborne source of exposure. 
This page intentionally left blank 


\section{APPENDIX D}

\section{ATMOSPHERIC TRITIUM EMISSIONS FROM DIFFUSE SOURCES}

\section{BACKGROUND INFORMATION}

Environmental monitoring for tritium in atmospheric moisture was conducted at ten locations on the NTS during 2000. There were four air samplers around the perimeter of RWMS-5 because many curies of ${ }^{3} \mathrm{H}$ are buried at that facility. Other air samplers, operated at locations with levels of tritium greater than the MDC, were operated at the E Tunnel pond area, near the SEDAN crater, and at SCHOONER. The monitoring results from the airborne-tritium sampling stations are provided in Table D.1.

The other CY 2000 monitoring data indicate that gross beta and ${ }^{239+240} \mathrm{Pu}$ concentrations in air at RWMS-5 are not statistically different from sitewide NTS levels, excluding the results for Bunker 9-300, which again this year had levels significantly higher than all other locations with air particulate samplers.

\section{SOURCE TERM}

It is estimated that $0.62 \mathrm{Ci}(23 \mathrm{Gbq})$ of ${ }^{3} \mathrm{H}$ were emitted from RWMS-5 during 2000 . The method used to calculate this quantity is described below.

The mean annual airborne HTO concentrations from the tritium samplers surrounding the RWMS were used along with the DOE/EH-0071 dose conversion factors to calculate a dose at each sampler location. For example, an individual breathing $3.7 \mathrm{pCi} / \mathrm{mL}$ of $\mathrm{HTO}$ (at RWMS No. 4) for one year receives $3.0 \times 10^{-3}$ mrem EDE when skin absorption is included ${ }^{1}$. Doses are calculated similarly for the other sampler locations. The result of a CAP88-PC run, assuming a $1 \mathrm{Ci}$ release of ${ }^{3} \mathrm{H}$ at the center of the RWMS, is that an individual $430 \mathrm{~m}$ to the northeast (at HTO sampler RWMS No. 4) would receive an EDE of $4.9 \times 10^{-3}$ mrem per year. Therefore, 3.0 measured at that sampler divided by $4.9 / \mathrm{Ci}$ (from CAP88PC) equals an estimated annual release of $0.62 \mathrm{Ci}$. This calculation was performed for all sampler locations. As shown in Table D.1, a release of $0.62 \mathrm{Ci}(23 \mathrm{GBq})$ was the maximum from RWMS-5.

The other samplers with elevated mean concentration of HTO in air are at the Area 10 SEDAN crater, Area 20 SCHOONER, and the E Tunnel Pond. The E Tunnel Pond emission is calculated in Appendix B. The emission from the SEDAN crater (calculated from air sampler data as above) is shown in the table, assuming SEDAN is the source. It appears unlikely that as much as $310 \mathrm{Ci}$ of $\mathrm{HTO}$ are being emitted from the SEDAN crater. However, there is no other likely source for the tritium measured in atmospheric moisture in that area. Therefore, the $E$ Tunnel Pond, RWMS-5, SEDAN crater, and SCHOONER are considered to be sources for emission of HTO on the NTS.

(1) The following equation was used to calculate an EDE at each sampler location.

$\mathrm{EDE}=\mathrm{pCi} / \mathrm{m}^{3} \times 8,400 \mathrm{~m}^{3} / \mathrm{yr}$ (inhaled) $\times 1.5$ (skin abs.) $\times 6.4 \times 10^{-8} \mathrm{mrem} / \mathrm{pCi}$ where $\mathrm{pCi} / \mathrm{m}^{3}$ is the annual average HTO concentration. 
Table D.1 Airborne Tritium Sampling Results During CY - 2000

\begin{tabular}{|c|c|c|c|c|c|c|}
\hline \multirow[b]{2}{*}{ Sampler Number } & \multirow{2}{*}{\multicolumn{2}{|c|}{ Coordinates $^{(a)}$}} & \multicolumn{2}{|c|}{ Mean } & \multirow[b]{2}{*}{ Emission $^{(\mathrm{c})}(\mathrm{Ci})$} & \multirow[b]{2}{*}{ Comment } \\
\hline & & & $\mathrm{pCi} / \mathrm{m}^{3}$ & $\mathrm{~Bq} / \mathrm{m}^{3}$ & & \\
\hline BJY & & & 1.0 & 0.037 & & Historical samples \\
\hline RWMS No. 4 & $\mathrm{NE}$ & $430 \mathrm{~m}$ & 3.7 & 0.14 & 0.62 & \\
\hline RWMS No. 7 & W & $295 \mathrm{~m}$ & 2.4 & 0.090 & 0.23 & \\
\hline RWMS No. 9 & $S$ & $313 \mathrm{~m}$ & 1.1 & 0.040 & 0.14 & \\
\hline WEF NE & SE & $424 \mathrm{~m}$ & 3.2 & 0.12 & 0.54 & \\
\hline Well 5B & & & -0.20 & -0.007 & --- & Background \\
\hline SEDAN Crater & $\mathrm{N}$ & $1290 \mathrm{~m}$ & 18. & 0.67 & 310. & \\
\hline E Tunnel Pond & & & 13. & 0.48 & 15. & Use evaporation \\
\hline Area 15 Farm & & & 5.7 & 0.21 & --- & SEDAN effluent \\
\hline SCHOONER & WNW & $269 \mathrm{~m}$ & 200.0 & 10. & 90. & \\
\hline
\end{tabular}

(a) Sampler direction and distance from center of suspected source.

(b) Median MDC is $2.2 \times 10^{-12} \mu \mathrm{Ci} / \mathrm{mL}$.

(c) Estimated number of curies emitted from the source that would give the sampler result. 


\section{APPENDIX E}

\section{RESUSPENDED PLUTONIUM FROM YUCCA FLAT AND OTHER AREAS}

\section{BACKGROUND INFORMATION}

Areas 1-12 and 15-20 on the NTS, Area 13 on the NAFR, and the CLEAN SLATE sites on the NAFR at the Tonopah Test Range contain diffuse sources of radionuclide effluents. Due to occasional high winds, some contaminated soil becomes airborne. Results from the air samplers, in these areas, indicate that ${ }^{239+240} \mathrm{Pu}$ is routinely detected, but only in concentrations slightly above the MDC. Only a few of the 23 air sampler locations on the NTS had concentrations exceeding the background level by four standard deviations (the criterion used for a high result).

\section{SOURCE TERM FROM RESUSPENSION CALCULATIONS}

A conservative estimate of plutonium emissions from diffuse sources is obtained by the use of a resuspension equation with parameters derived from actual studies at the NTS. In NUREG/CR3332 (NRC 1983), page 5-30, an equation for calculating a suspension rate (fraction resuspended per second) is given as follows:

$$
S=K \times V_{g}
$$

where: $S$ = suspension rate $\left(\mathrm{sec}^{-1}\right)$ - fraction of the deposit resuspended/sec

$\mathrm{K}=$ resuspension factor $\left(\mathrm{m}^{-1}\right)$

$\mathrm{V}_{\mathrm{g}}=$ deposition velocity $(\mathrm{m} / \mathrm{s})$

On page 75 of report DOE/NV--357 (DOE 1992), values of $\mathrm{K}$ are given for the NTS. An average of the values given is $2 \times 10^{-1} / \mathrm{m}$. Deposition velocities in the range of 0.01 to $0.05 \mathrm{~m} / \mathrm{s}$ will be used as conservative estimates. If these values are put into the above equation, the rate of resuspension is between $2 \times 10^{-12}$ and $1 \times 10^{-11} / \mathrm{s}$. To be conservative, the higher resuspension rate of $1 \times 10^{-11} / \mathrm{s}$ will be used. For Area 3, the source term rate is then calculated from the product of the ${ }^{239+240} \mathrm{Pu}$ deposition $(37 \mathrm{Ci}$ ) from Table 1.0 and resuspension rate, as follows:

$$
37 \mathrm{Ci} \times 10^{12} \mathrm{pCi} / \mathrm{Ci} \times 1 \times 10^{-11} / \mathrm{s}=370 \mathrm{pCi} / \mathrm{s} \text {. }
$$

Since 1 year = 3,600 s/hr $\times 24 \mathrm{hr} /$ day $\times 365$ days $/ \mathrm{yr}=3.15 \times 10^{7} \mathrm{sec} / \mathrm{yr}$, the annual source term becomes:

$$
370 \mathrm{pCi} / \mathrm{s} \times 3.15 \times 10^{7} \mathrm{~s} / \mathrm{yr}=1.17 \times 10^{10} \mathrm{pCi} / \mathrm{yr}(12 \mathrm{mCi} / \mathrm{yr}) \text {. }
$$

This method was used for calculating the ${ }^{241} \mathrm{Am}$ and ${ }^{239+240} \mathrm{Pu}$ emissions from all other areas. The results are shown at the end of Table E.1. The EDEs for each of the areas were then determined from CAP88-PC calculations using the individual area emission rates. The results are listed in Table 5.0.

\section{OTHER ISOTOPES}

The other predominant isotopes that have been found in soil samples in the various areas on the NTS are ${ }^{137} \mathrm{Cs}$ and ${ }^{238} \mathrm{Pu}$. The cesium isotope is neglected because it migrates readily and, in eight to ten years after assessment in the soil, only a fraction will remain in the surface layer. Since the ${ }^{238} \mathrm{Pu}$ concentration in air is usually below the minimum detectable concentration, this isotope has also not been included in evaluations for NESHAP compliance. 
Table E.1 Calculated Emissions from Resuspension of Plutonium and Americium in NTS Areas

\begin{tabular}{|c|c|c|c|c|c|c|}
\hline \multicolumn{7}{|c|}{$\mathrm{S}($ Resuspension in $\mathrm{Ci})=\mathrm{Ci} \times \mathrm{K} \times \mathrm{Vg} \times 1 \mathrm{E}+03 \mathrm{mCi} / \mathrm{Ci} \times 3.15 \mathrm{E}+07 \mathrm{~s} / \mathrm{yr}$} \\
\hline Area & $\begin{array}{l}{ }^{241} \mathrm{Am} \\
(\mathrm{Ci})\end{array}$ & $\begin{array}{c}{ }^{239+240} \mathrm{Pu} \\
(\mathrm{Ci})\end{array}$ & $\begin{array}{c}\mathrm{K} \\
\left(\mathrm{m}^{-1}\right)\end{array}$ & $\begin{array}{c}\mathrm{Vg} \\
(\mathrm{m} / \mathrm{s})\end{array}$ & $\begin{array}{l}\mathrm{S} \text { for }{ }^{241} \mathrm{Am} \\
(\mathrm{mCi} / \mathrm{yr})\end{array}$ & $\begin{array}{c}\mathrm{S} \text { for } \\
(\mathrm{mCi} / \mathrm{yr})\end{array}$ \\
\hline 1 & 4.2 & 24 & 2.E-10 & 5.E-02 & 1.32 & 7.6 \\
\hline 2 & 2.9 & 22 & 2.E-10 & 5.E-02 & 0.91 & 6.9 \\
\hline 3 & 4.6 & 37 & 2.E-10 & 5.E-02 & 1.45 & 11.7 \\
\hline 4 & 6.6 & 40 & 2.E-10 & 5.E-02 & 2.08 & 12.6 \\
\hline 5 & 0.6 & 4.8 & 2.E-10 & 5.E-02 & 0.19 & 1.5 \\
\hline 6 & 1.7 & 8.4 & 2.E-10 & 5.E-02 & 0.54 & 2.6 \\
\hline 7 & 2.2 & 16 & 2.E-10 & 5.E-02 & 0.69 & 5.0 \\
\hline 8 & 17. & 110 & 2.E-10 & 5.E-02 & 5.36 & 34.7 \\
\hline 9 & 4.2 & 89 & 2.E-10 & 5.E-02 & 1.32 & 28.0 \\
\hline 10 & 19. & 110 & 2.E-10 & 5.E-02 & 5.99 & 34.7 \\
\hline 11 & 3.3 & 29 & 2.E-10 & 5.E-02 & 1.04 & 9.1 \\
\hline 12 & 5.7 & 39 & 2.E-10 & 5.E-02 & 1.80 & 12.3 \\
\hline 15 & 8. & 63 & 2.E-10 & 5.E-02 & 2.52 & 19.8 \\
\hline 16 & 0.7 & 3.7 & 2.E-10 & 5.E-02 & 0.22 & 1.2 \\
\hline 17 & 2.8 & 18 & 2.E-10 & 5.E-02 & 0.88 & 5.7 \\
\hline 18 & 19. & 100 & 2.E-10 & 5.E-02 & 5.99 & 31.5 \\
\hline 19 & 21. & 140 & 2.E-10 & 5.E-02 & 6.62 & 44.1 \\
\hline 20 & 23. & 41 & 2.E-10 & 5.E-02 & 7.25 & 12.9 \\
\hline 30 & 3.2 & 14 & 2.E-10 & 5.E-02 & 1.01 & 4.4 \\
\hline TOTAL & 140 & 910 & & & 47. & 290 \\
\hline \multicolumn{7}{|l|}{ Offsite } \\
\hline 13 & 2.88 & 46 & 2.E-10 & 5.E-02 & 0.91 & 14.5 \\
\hline CS II & 1.06 & 17 & 2.E-10 & 5.E-02 & 0.33 & 5.4 \\
\hline CS III & 2.31 & 37 & 2.E-10 & 5.E-02 & 0.73 & 11.7 \\
\hline \multirow[t]{2}{*}{ TOTAL } & 6.3 & 100 & & & 2.0 & 32 \\
\hline & \multicolumn{5}{|c|}{$\begin{array}{l}\text { Radioactive inventories from Table } 5 \text { in DOE/NV/108545-02 except for Area } 13 \\
\text { and Clean Slates where Pu-239/240 inventories are from Table } 3-13 \text { in DOE/NV- } \\
357 \text { (Revision 2) and Am-241 inventories calculated from } 1 / 16 \text { of } \\
\text { Pu-239/240 inventories. }\end{array}$} & \\
\hline
\end{tabular}




\section{EPA METHOD FOR ESTIMATING DIFFUSE EMISSIONS}

Using the equation in EPA's Methods for Estimating Diffuse Emissions (unpublished), a wind erosion calculation for Area 9 for comparison with the NTS NESHAPs report calculation can be done. To illustrate this calculation, the equation on page 18 of the EPA report is used:

$$
E^{\prime}=k \cdot a \cdot I \cdot K \cdot C \cdot L^{\prime} \cdot V^{\prime} \cdot A \cdot C
$$

where: $\quad E^{\prime}=$ soil particles lost (tons/yr)

$\mathrm{k}=$ particle size factor

$\mathrm{a}=$ total suspended fraction lost to wind erosion

$\mathrm{I}=$ soil erodibility (tons/acre-yr)

$\mathrm{K}=$ surface roughness factor

$C=$ climatic factor $-\mathrm{C}=0.345\left(\mathrm{mph}^{3} / \mathrm{PE}^{2}\right)$ where $\mathrm{PE}=0.83$

$L^{\prime}=$ unsheltered field width factor

$\mathrm{V}^{\prime}=$ vegetative cover factor

$A=$ site area $\left(\mathrm{m}^{2}\right)$ - use high density of $75.6 \mathrm{Ci}$ on $7.5 \mathrm{mi}^{2}$

$c=$ conversion factor tons/acre to $\mathrm{kg} / \mathrm{m}=0.224$

Inputs: Yucca Flat is typical high plain desert with sparse vegetation. Average wind speed is $6.0 \mathrm{knots}=6 \times 0.514 \mathrm{~m} / \mathrm{s}=3.08 \mathrm{~m} / \mathrm{s}=11.1 \mathrm{~km} / \mathrm{hr}(6.9 \mathrm{mph})$.

$k=0.5$ (fraction of resuspended soil that is $\mathrm{PM}_{10}$ )

$\mathrm{a}=0.025$ portion of total erosion that is suspended particulates

$\mathrm{I}=28$ (silty clay loam from Table $7-1$, desert pavement decreases erodibility)

$\mathrm{K}=1$ (surface roughness - desert is smooth)

$\mathrm{C}=164$ (climatic factor calculated from $\mathrm{C}=0.345(\mathrm{mph})^{3} /(0.83)^{2}$

$L^{\prime}=0.3$ as read from Figure $7-5(\mathrm{IK}=28 \times 0.6=17, \mathrm{~L}=500$ from Table $7-3)$

$V^{\prime}=0.95$ (read from Figure 7-6 using $V=100$ from Table 7-3 and IKCL'=790)

$A=7.5 \mathrm{mi}^{2}=1.9 \times 10^{7} \mathrm{~m}^{2}$ (from DOE 1991).

so

$E^{\prime}=0.5 \times 0.025 \times 28 \times 1 \times 164 \times 0.3 \times 0.95 \times 0.224=3.7 \mathrm{~kg} / \mathrm{m}^{2}-\mathrm{yr}$

Area 9 (from McArthur in "DOE/NV/10485--02"):

$89 \mathrm{Ci}$ on $20 \mathrm{mi}^{2}\left(20 \times 2.59 \times 10^{6} \mathrm{~m}^{2} / \mathrm{mi}^{2}\right)$ or $5.2 \times 10^{7} \mathrm{~m}^{2}$

Total Emission $=3.7 \mathrm{~kg} / \mathrm{m}^{2}-\mathrm{yr} \times 5.2 \times 10^{7} \mathrm{~m}^{2}=1.9 \times 10^{8} \mathrm{~kg} / \mathrm{yr}$

Plutonium concentration in dust (assuming all plutonium is in top $5 \mathrm{~cm}$ ):

$5.2 \times 10^{7} \mathrm{~m}^{2} \times 10^{4} \mathrm{~cm}^{2} / \mathrm{m}^{2} \times 5 \mathrm{~cm}$ deep $\times 1.5 \mathrm{~g} / \mathrm{cm}^{3}=3.9 \times 10^{12} \mathrm{~g}$

$89 \mathrm{Ci} \times 10^{12} \mathrm{pCi} / \mathrm{Ci} \div 3.9 \times 10^{12} \mathrm{~g}=23 \mathrm{pCi} / \mathrm{g}$ or $23 \mathrm{nCi} / \mathrm{kg}$

and the source-term becomes:

$$
23 \times 10^{-9} \mathrm{Ci} / \mathrm{kg} \times 1.9 \times 10^{8} \mathrm{~kg} / \mathrm{yr}=4.4 \mathrm{Ci} / \mathrm{yr}
$$

If the total deposit in Area 9 is $89 \mathrm{Ci}$ and if the $\mathrm{E}^{\prime}$ calculation performed above is correct, then $89 \mathrm{Ci} \div 4.4 \mathrm{Ci} / \mathrm{yr}=20.2$ suggests that the deposit would be depleted in little more than 20 years.

The resuspension equation calculation for Area $9(0.028 \mathrm{Ci} / \mathrm{yr})$ in Table $\mathrm{E}-1$ would require about 3,200 years to deplete the deposit. 
This page intentionally left blank 


\section{APPENDIX F}

\section{IDENTIFICATION AND JUSTIFICATION FOR THE DEVELOPMENT OF METEOROLOGICAL DATA USED AS INPUT TO CAP88-PC}

\section{INTRODUCTION}

The NTS is located in southern Nevada, approximately $105 \mathrm{~km}$ (65 mi) northwest of Las Vegas, Nevada and encompasses an approximate rectangular area of approximately $1,375 \mathrm{mi}^{2}$ (see Figure F.1). Topography is complex with generally north-south oriented ridges and valleys typical of Nevada. Terrain elevations range from almost 2,700 ft in the extreme southwest corner of the NTS (Station No. 25) to almost 7,700 ft on Rainier Mesa in the northern part of the NTS (Station No. 12).

In general, terrain slopes gently into broad valleys. In the few areas where steep canyons or cliffs exist, adequate wind and temperature data have been collected and analyzed to provide thorough documentation of the existence of typical up-slope and down-slope wind regimes as a function of time of day.

Meteorological support, observations, and climatological services for the NTS are provided to the NNSA/NV by the ARL/SORD. The ARL/SORD is a National Oceanic and Atmospheric Administration (NOAA) office and supports NNSA/NV programs under the authority of an Interagency Agreement between NOAA and NNSA/NV.

An arid climate exists over the NTS. Annual precipitation ranges from $4.5 \mathrm{in} / \mathrm{yr}$ at Station No. 25 to $6.8 \mathrm{in} / \mathrm{yr}$ at Yucca Flat (Station No. 6) to $7.6 \mathrm{in} / \mathrm{yr}$ at Desert Rock, to $12.8 \mathrm{in} / \mathrm{yr}$ on Rainier Mesa (Station No. 12).

\section{METEOROLOGICAL OBSERVATIONS}

The ARL/SORD manages, operates, and maintains a meteorological monitoring program that is designed and used to support the NNSA/NV authorized activities on the NTS. This vital program consists of many meteorological monitoring systems that have been brought together under the acronym MIDNET, or Meteorological Integrated Data Network. This network has been operated on the NTS for over 30 years, has undergone several modernizations and upgrades, and serves as a solid basis for deriving climatological information.

MIDNET consists of communications systems, local area networks, upper air sounding stations, and surface based instrumentation used to measure wind direction and speed, temperature, relative humidity, and precipitation. Routine and special surface observations are collected by trained ARL/SORD personnel $16 \mathrm{hr} /$ day, 365 days/yr at the Desert Rock Meteorological Observatory (DRA, elevation 3,304 ft) located three miles southwest of Mercury, Nevada (Station No. 23). Upper-air observations (radiosondes) are taken twice daily from DRA. DRA has been in operation since May 1978. DRA was built to replace a similar observatory that was located at the Yucca Flat Meteorological Observatory (UCC, elevation 3,924 ft, Station No. 6) from January 1962 through mid May 1978. Consequently, surface and upper-air observations are also available from UCC for 1962-1978. 


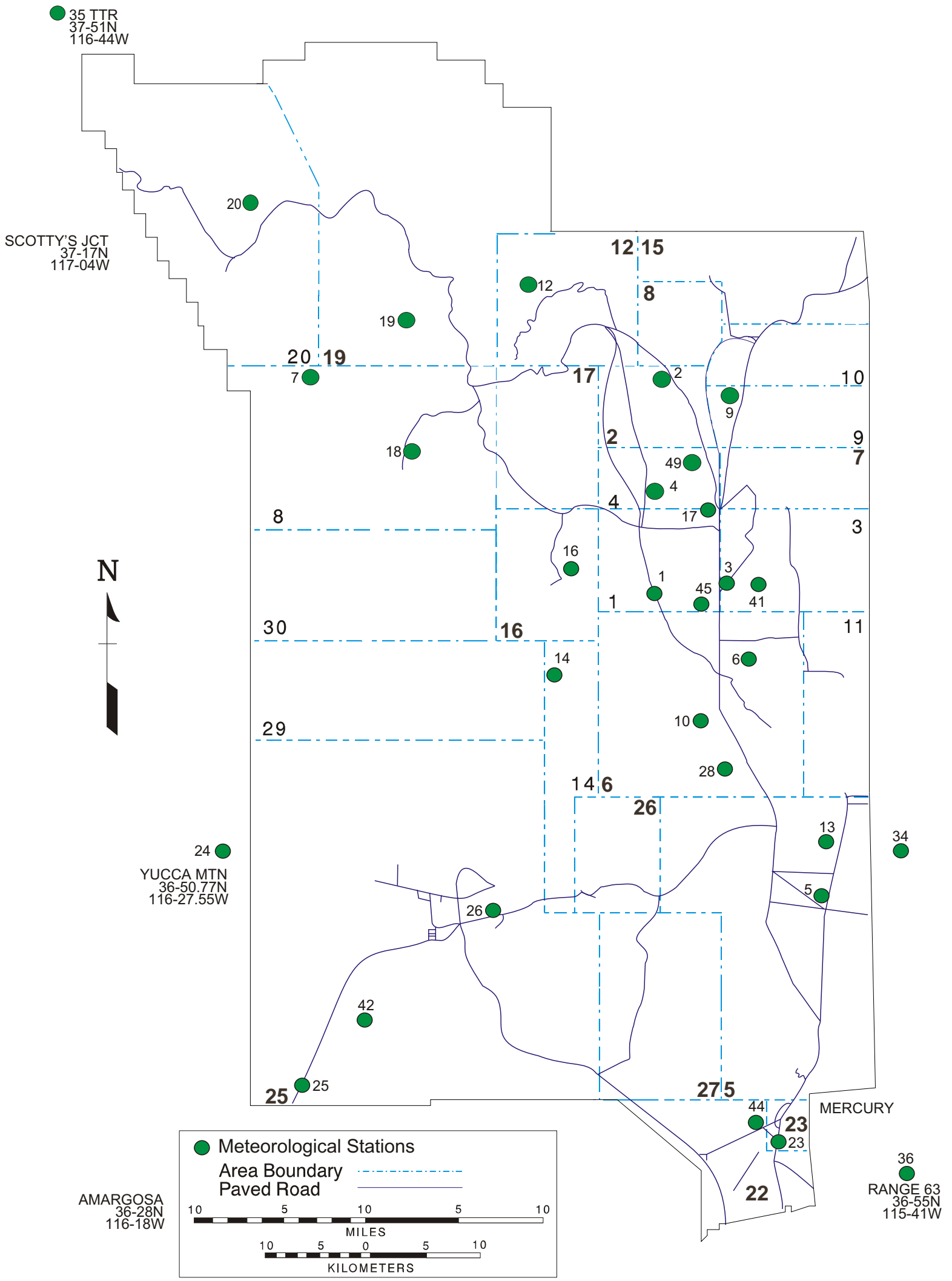

Figure F.1 Locations of Meteorological Data Acquisition System (MEDA) Stations on the NTS $\mathrm{F}-2$ 
A key component of the MIDNET system is the MEDA. The MEDA consists of an enclosed trailer, a portable 10-m tower, (an electric generator where needed), a microprocessor, and a microwave radio transmitter. Wind speed and direction sensors are located on booms oriented into the prevailing wind direction and at a minimum distance of two tower widths from the tower. Wind sensors are located $10 \mathrm{~m}$ above the ground.

Wind and temperature data have been collected on the NTS for more than 40 years. These and other meteorological data have been compiled into a comprehensive climatological database for the NTS. The MEDA data are specially useful in assessing boundary layer flow regimes on the NTS. MEDA station distribution and density (see Figure F.1) are sufficient to document individual basin flow regimes and potential inter-basin air exchanges.

Ambient temperature and relative humidity sensors are located at the 3-m level. A total of 30-40 MEDA stations are located on or around the NTS (see Figure F.1) to ensure that meteorological conditions are thoroughly documented for the complex terrain environment found on the NTS.

Wind direction is measured to two degrees of azimuth and wind speed is accurate to $0.85 \mathrm{mph}$. Wind data are collected as 5 minute averages and are transmitted via microwave to a central processor every 15 minutes. These data are checked operationally by the duty forecaster and quality control is assured by the ARL/SORD climatologist. Plotted wind products are generated every 15 minutes for operational use. The data are stored and archived for climatological purposes.

MEDA temperature is accurate to $1^{\circ} \mathrm{F}$ between $0^{\circ} \mathrm{F}$ and $110^{\circ} \mathrm{F}$ (absolute range for the NTS is $-20^{\circ} \mathrm{F}$ to $115^{\circ} \mathrm{F}$ ). Temperature measurements are instantaneous and are taken every 15 minutes at all MEDA stations. These data are also transmitted via microwave to a computer for processing, display, and archiving.

To utilize the most representative meteorological data available for NTS sources, cloud observations from DRA were melded with the concomitant MEDA winds from Mercury and Pahute Mesa. Similarly, the cloud observations from UCC were melded with MEDA wind data from Yucca and Frenchman Flats. The straight-line distance from DRA to Mercury is 3 miles; from UCC to Frenchman Flat, 12 miles; and from DRA to Pahute Mesa, 40 miles.

Cloud cover observations needed as input to the STAR program are available from DRA (1978-present) and from UCC (1962-1978). Based on the available data, the cloud cover climatology from DRA and UCC are quite compatible. For example, UCC experiences 192 clear days annually, while DRA has 191 days. In addition, the average annual sky cover, in tenths, from sunrise to sunset for both stations is 3.9 tenths daily. The total number of cloudy days for UCC is 81 days and 88 days for DRA, annually. Therefore, the cloud cover observations from DRA and UCC can be considered as representative for most of the NTS.

In a study of precipitation on the NTS, Quiring (1983) found that the northwest part of the NTS, including Pahute Mesa, is clearly an area of diminished precipitation for the given elevation $(6,500 \mathrm{ft})$. Furthermore, the total annual precipitation for Pahute Mesa (7.9 inches) is more compatible with that from DRA (7.6 inches) than from UCC (6.8 inches). Consequently, assuming that cloud cover is directly related to precipitation, it logically follows that the cloud cover for Pahute Mesa is better represented climatologically by the cloud observations from DRA.

\section{CONCLUSIONS}

Based on the above considerations and on the limitations of CAP88-PC, the cloud cover data from DRA were considered to be representative of Pahute Mesa. Therefore, atmospheric 
soundings and cloud cover observations from DRA were melded with MEDA surface wind data from Pahute Mesa for input to the STAR program to provide the very best data for calculating transport and dispersion processes.

For sources in Yucca Flat and Frenchman Flat, the cloud cover data from UCC were considered to be the most representative. Yucca Flat and Frenchman Flat are adjoining valleys of similar soil and vegetation types and similar meteorological and climatological conditions.

For sources at Mercury, the cloud observations from DRA are representative. DRA is only 3 miles from Mercury.

The STAR file is a matrix that includes 6 Pasquill stability categories (A through F), 6 wind speed categories, and 16 wind sectors from wind roses calculated for each specified MEDA station on the NTS. Although no weather data during the year 2000 were used in creating the STAR file for CAP88-PC calculations, the data used over the period 1983 to 1995 is considered representative. 


\section{APPENDIX G \\ DOSE ASSESSMENT FOR MODIFICATION OF AREA 6 DEVICE ASSEMBLY FACILITY}

The DAF modification to include two glove boxes with appropriate air handling system was to provide a safe and secure location at which the plutonium targets for the Area 27 two-stage light gas gun (Project JASPER) could be handled and prepared for experiments. As required by Title 10 of the Code of Regulations, Part 61, Subpart H (NESHAP), a dose assessment was conducted to determine whether an application for EPA approval under section 61.07 or notification of startup under section 61.09 was necessary.

From the following specifications and operating conditions, the annual Pu source-term for the glove boxes was calculated for ${ }^{238} \mathrm{Pu}$ and ${ }^{239} \mathrm{Pu}$.

Given: Target weight: $2.5 \mathrm{~g}{ }^{238} \mathrm{Pu}$ and $200 \mathrm{~g}{ }^{239} \mathrm{Pu}$

Stack height: $14 \mathrm{~m}$ (32 ft building height $+12 \mathrm{ft}$ stack height)

Stack diameter: $0.064 \mathrm{~m}$ (2.5 in diameter)

Stack velocity: $0.19 \mathrm{~m} / \mathrm{s}$ ( $5 \mathrm{cfm}$ through 2.5 in diameter stack)

NESHAP emission factor for a solid: $1 \times 10^{-6}$ (40 CFR 61, Appendix D)

NESHAP adjustment factor for HEPA filter: 0.01

Adjustment factor for 2 HEPA filters in series: $1 \times 10^{-4}$

Number of targets per year: 26

Map coordinates for release stack: $782,766 \mathrm{~N} \quad 681,193 \mathrm{E}$

Pu-238 half-life: 87.74 y (ICRP 30)

Pu-239 half life: 24,065 y (ICRP 30)

\section{${ }^{238} \mathrm{Pu}$ Source-Term Calculation}

$2.5 \mathrm{~g} /$ target $\times 26$ targets $/ \mathrm{yr} \times 1 \mathrm{~g}$-mole/238 g x $6.023 \mathrm{E} 23$ atoms $/ \mathrm{g}$-mole $\times 0.693$ dis/87.74yr-atom $x$ 1yr/525,600 $\mathrm{min} \times 1 \mathrm{~min}-\mathrm{Ci} / 2.22 \mathrm{E} 12$ dis $\times 1 \mathrm{E}-06$ x $1 \mathrm{E}-04=1.1 \mathrm{E}-07 \mathrm{Ci} / \mathrm{yr}$

\section{${ }^{239} \mathrm{Pu}$ Source-Term Calculation}

200g/target x 26 targets/yr x $1 \mathrm{~g}$-mole/239g x6.023 E23 atoms/g-mole x 0.693 dis/24,065yr-atom $\mathrm{x} 1 \mathrm{yr} / 525,600 \mathrm{~min} \times 1 \mathrm{~min}-\mathrm{Ci} / 2.22 \mathrm{E} 12$ dis $\times 1 \mathrm{E}-06$ x $1 \mathrm{E}-04=3.2 \mathrm{E}-08 \mathrm{Ci} / \mathrm{yr}$

Using CAP88-PC software and these source terms, the EDE for all residents within $80 \mathrm{~km}$ of the DAF stack was calculated. The MEI was determined to be at Crystal (46 km SSW from the DAF) or Lathrop Wells (42 km SW from the DAF) who would receive $1.2 \times 10^{-7} \mathrm{mrem} / \mathrm{yr}$ at either location. Since the EDE was considerably less than $0.1 \mathrm{mrem} / \mathrm{yr}$, an application or notification to the EPA was not necessary. 
This page intentionally left blank 


\title{
APPENDIX H \\ SUPPLEMENTAL INFORMATION
}

\section{COMPARISON WITH PREVIOUS YEARS' DATA}

\author{
Maximum Potential Individual EDE: $\quad 2000-1.7 \times 10^{-1} \mathrm{mrem}(1.7 \mu \mathrm{Sv})$ \\ $1999-1.2 \times 10^{-1} \mathrm{mrem}(1.2 \mu \mathrm{Sv})$ \\ $1998-9.2 \times 10^{-2}$ mrem $(0.9 \mu \mathrm{Sv})$ \\ $1997-9.0 \times 10^{-2} \mathrm{mrem}(0.9 \mu \mathrm{Sv})$ \\ $1996-1.1 \times 10^{-1} \mathrm{mrem}(1.1 \mu \mathrm{Sv})$ \\ $1995-1.8 \times 10^{-1} \mathrm{mrem}(1.8 \mu \mathrm{Sv})$ \\ $1994-1.5 \times 10^{-1} \mathrm{mrem}(1.5 \mu \mathrm{Sv})$ \\ $1993-3.8 \times 10^{-3} \mathrm{mrem}(38.0 \mathrm{nSv})$ \\ $1992-1.2 \times 10^{-2}$ mrem $(0.12 \mu \mathrm{Sv})$
}

In 1993, tunnel effluents began decreasing because of sealing the tunnel drainage systems. In 1994, resuspension of plutonium from surface deposits was calculated. The 1996 decrease is due to decreased emissions and cleanup of areas. The 1997 decrease was due to decreased emissions, cleanup of areas, and a slight population decrease. The small increase for 1998 is due to increased emissions of tritium, and, for 1999 , the increase is due to the inclusion of ${ }^{241} \mathrm{Am}$. Finally, the increase for $\mathbf{2 0 0 0}$ was due to the addition of NTS areas not previously included in the resuspension calculations.

\section{COLLECTIVE EFFECTIVE DOSE EQUIVALENT}

The maximum potential collective EDE to the 38,381 people who live within $80 \mathrm{~km}$ of the NTS emission sources was 0.44 person-mrem in 2000 , due mostly to calculated resuspended plutonium and americium exposure. The collective EDE data are based on distance and direction from each of the sources of emission on the NTS to nearby areas. These data are displayed in the last column of Table 5.0. The collective EDE is the sum of the EDEs to the community from each emission source multiplied by the population of the community.

Maximum Potential Collective EDE (person-mrem) by NTS Source:

$\begin{array}{ll}\text { Areas } 3,4,9 & 89.6 \\ \text { Areas 5, 6, } 7 & 27 \\ \text { Area } 8,10 & 54 \\ \text { Area } 18 & 49.9 \\ \text { Areas 19, 20, 30 } & 55.8 \\ \text { Other Areas } & \begin{array}{l}159 \\$\cline { 2 - 2 }\end{array} \\ & 435 \text {$person-mrem } \\ & (0.44 \text { person-rem) }\end{array}$

The higher potential population doses from americium and plutonium areas are due to a revision in the conservative assumptions used in the resuspension calculations. This year additional NTS areas (Areas 1, 2, 4, 5, 6, 7, 12, 15, 16, 17, 19 and 30) were included in the resuspension calculations because of the deposition of fallout from tests in the other areas listed in Table 1.0. The extent of overestimation is shown by the calculation displayed in Table 6.0. The EDE calculation, based upon the average of the concentrations measured at the six offsite locations was $25 \mu \mathrm{rem}$, whereas an average of $56 \mu \mathrm{rem}$ was estimated from CAP88 calculations for the same locations, a factor of 2.2 higher than the measured concentrations. 


\section{COMPLIANCE WITH NESHAPs}

NNSA/NV was in compliance with Title 40 CFR 61, Subpart $\mathrm{H}$, during CY 2000. Periodic confirmatory measurements and analyses of the NTS environs are provided in Appendices A through $\mathrm{E}$. These measurements and analyses are the methods of determining NTS effluents presented in the April 24, 1991, meeting between Region 9 and NNSA/NV.

\section{COMPLIANCE WITH SUBPARTS Q AND T, Title 40 CFR 61}

The NTS is regulated by Subpart $\mathrm{H}$ (National Emission Standards for Emissions of Radionuclides Other Than Radon from DOE Facilities), but not Q (National Emission Standards for Radon Emissions from DOE Facilities) and T (National Emission Standards for Radon Emissions from the Disposal of Uranium Mill Tailings). However, Bechtel Nevada includes Subpart Q in its Work Smart Standards. Therefore, radon flux measurements were made during this report period at the Area 3 RWMS and the Area 5 RWMS to confirm inventory records that only trace amounts of radium were disposed of in these areas and to make sure that the radon fluxes are well below the standard of $20 \mathrm{pCi} / \mathrm{m}^{2} / \mathrm{s}$ required by Subpart $\mathrm{Q}$ in the event that by-product material as defined by section 11.e(2) of the Atomic Energy Act of 1954 (as amended) is disposed of in these areas in the future. The results of the most recent study (DOE 2001) showed that the airborne concentrations of radon and the flux measurements of radon were both at background levels. An assessment of the potential risks posed by the RWMS-5 to the public projected that the in-growth of ${ }^{222} \mathrm{Rn}$ from the decay of ${ }^{230} \mathrm{Th}$ in thorium wastes would not exceed the standard for approximately 30,000 years (Shott et al., 1998).

\section{RADON EMISSIONS FROM ${ }^{238} U$ AND ${ }^{232}$ Th SOURCES}

In the past, material from Mound Applied Technologies containing these sources was stored in cargo containers at the RWMS-5. However, since the shipment of these containers offsite in 1997 , none of these sources are present at the NTS.

\section{NON-DISPOSAL/NON-STORAGE SOURCES OF RADON EMISSION}

None of these sources exist on the NTS.

\section{QUALITY ASSURANCE PROGRAM NESHAP}

Provisions in Method 114 described in Appendix B of Title 40 CFR 61 are related to continuous monitoring of major sources. The NTS has only minor sources. 


\section{APPENDIX I}

\section{REFERENCES}

Code of Federal Regulations, 1989, "National Emission Standards for Hazardous Air Pollutants: Radionuclides," Title 40 CFR Part 61, U.S. Environmental Protection Agency, Washington, DC.

DOE, see U.S. Department of Energy.

Energy Research and Development Administration, 1977, "Final Environmental Impact Statement, Nevada Test Site, Nye County, Nevada," Report ERDA-1551, Washington, DC.

EPA, see U.S. Environmental Protection Agency.

Federal Facilities Agreement and Consent Order (FFACO), 1996, An FFACO among the State of Nevada, the U.S. Department of Energy, and the U.S. Department of Defense, May 1996.

Hardcastle, J., 2000, "Nevada County Population Estimates July 1, 1986 to July1, 2000" Nevada Department of Taxation State Demographer Office, University of Reno, Reno, NV.

International Commission on Radiological Protection (ICRP), 1990, "Limits for Intake by Workers," ICRP Publication 30, Supplement to Part 1, Pergamon Press, New York.

NRC, see U.S. Nuclear Regulatory Commission.

Quiring, R.F., 1983, "Precipitation Climatology for the NTS," NOAA Weather Service Nuclear Service Office (WSNSO), WSNSO351-88, Las Vegas, NV.

Shott, G. J., et al, January 1998, "Performance Assessment for the Area 5 Radioactive Waste Management Site at the Nevada Test Site, Nye County, Nevada," ( DOE/NV/11718--176, UC-721), U.S. Department of Energy, 1998, Nevada Operations Office, Las Vegas, NV.

U.S. Department of Energy, 1991, "Radionuclides in Surface Soil at the Nevada Test Site," Report DOE/NV/10485--02, Water Resources Center, Desert Research Institute, University of Nevada System, Las Vegas, NV.

U.S. Department of Energy, 1992, "Summary of the Nevada Applied Ecology Group and Correlative Programs," Report DOE/NV--357, Ratheon Services Nevada, Las Vegas, NV.

U.S. Department of Energy, 1996a, "Final Environmental Impact Statement for the Nevada Test Site and Off-Site Locations in the State of Nevada," Report DOE/EIS 0243 Nevada Operations Office, Las Vegas, NV.

U.S. Department of Energy, 1996b, "National Emission Standards for Hazardous Air Pollutants Submittal - 1995," Report DOE/NV/11718--032, Bechtel Nevada, Las Vegas, NV.

U.S. Department of Energy, 1997a, "Nevada Environmental Restoration Project, Double Tracks Closure Report," Report DOE/NV-17718--113, UC-802, Bechtel Nevada, Las Vegas, NV. 


\section{$\underline{\text { References, cont. }}$}

U.S. Department of Energy, 1997b, "Nevada Environmental Restoration Project, Clean Slate I Closure Report," Report DOE/NV-17718--159, UC-702, Bechtel Nevada, Las Vegas, NV.

U.S. Department of Energy, 2000, "United States Nuclear Tests: July 1945 through September 1992." Report DOE/NV--209 (Revision 15), Nevada Operations Office, Las Vegas, NV.

U.S. Department of Energy, 2001, "Nevada Test Site 2000 Waste Management Monitoring Report, Area 3 and Area 5 Radioactive Waste Management Sites," Report DOE/NV/11718--582, Nevada Operations Office, Las Vegas, NV.

U.S. Environmental Protection Agency, 1992, "User's Guide for CAP88-PC, Version 1.0," Report 402-B-92-001, Office of Radiation Programs, Las Vegas, NV.

U.S. Nuclear Regulatory Commission, 1983, "Radiological Assessment," Report NUREG/CR-3332, J.E. Till and H.R. Meyer Editors, Office of Nuclear Reactor Regulation, Washington, DC. 


\section{APPENDIX $\mathbf{J}$}

\section{DISTRIBUTION LIST}

K. P. Webb, Office of Primaries and Test Readiness, (DP-132 GTN), U.S. Department of Energy, 19901 Germantown Road, Germantown, MD 20545

D. M. Miotla, Office of Facilities Management, (DP-17 GTN), U.S. Department of Energy, 19901 Germantown Road, Germantown, MD 20545

R. P. Berube, Acting Director, Office of Environmental Policy and Assistance, (EH-41 FORS), U.S. Department of Energy, 1000 Independence Avenue SW, Washington, DC 20585

R. L. Natoli, Office of Environmental Policy and Assistance, (EH-412 FORS), U.S. Department of Energy, 1000 Independence Avenue SW, Washington, DC 20585

G. Vazquez, Office of Environmental Policy and Assistance, (EH-412 FORS), U.S. Department of Energy, 1000 Independence Avenue SW, Washington, DC 20585 (3)

R. Anderson, Program Manager, Office of Radiation and Indoor Air, U.S. Environmental Protection Agency, 1200 Pennsylvania Avenue NW, Washington, DC 20460

D. P. Howekamp, Director, Air Division, Region 9, U.S. Environmental Protection Agency, 75 Hawthorne Street, San Francisco, CA 94103

S. Rosenblum, Air Division, Region 9, U.S. Environmental Protection Agency, 75 Hawthorne Street, San Francisco, CA 94103

K. D. Izell, Assistant Manager for Technical Services, Nevada Operations Office, National Nuclear Security Administration U.S. Department of Energy, P. O. Box 98518, Las Vegas, NV 89193-8518, M/S 505

D. D. Monette, Assistant Manager for National Security, Nevada Operations Office, National Nuclear Security Administration, U.S. Department of Energy, P. O. Box 98518, Las Vegas, NV 89193-8518, M/S 505

C. P. Gertz, Assistant Manager for Environmental Management, Nevada Operations Office, National Nuclear Security Administration, U.S. Department of Energy, P. O. Box 98518, Las Vegas, NV 89193-8518, M/S 505

K. A. Hoar, Director, Environment, Safety \& Health Division, Nevada Operations Office, National Nuclear Security Administration, U.S. Department of Energy, P. O. Box 98518, Las Vegas, NV 89193-8518, M/S 505 (3)

R. C. Wycoff, Director, Environmental Restoration Division, Nevada Operations Office, National Nuclear Security Administration, U.S.Department of Energy, P. O. Box 98518, Las Vegas, NV 89193-8518, M/S 505

E. F. DiSanza, Director, Waste Management Division, Nevada Operations Office, National Nuclear Security Administration, U.S. Department of Energy, P. O. Box 98518, Las Vegas, NV 89193-8518, M/S 505 (3) 


\section{Distribution, cont.}

B. Hurley, Environment, Safety \& Health Division, Nevada Operations Office, National Nuclear Security Administration, U.S. Department of Energy, P. O. Box 98518, Las Vegas, NV 89193-8518, M/S 505

Office of Scientific and Technical Information, U.S. Department of Energy,

P. O. Box 62, Oak Ridge, TN 37831 (1 - electronic)

Technical Information Resource Center, Nevada Operations Office, National Nuclear Security Administration, U.S. Department of Energy, P. O. Box 98518, Las Vegas, NV 89193-8518, M/S 505

G. Dempsey, Director, Center for Environmental Restoration, Monitoring \& Emergency Response, U.S. Environmental Protection Agency, P. O. Box 93478, Las Vegas, NV 89193-3478, M/S 513

D. A. Bedsun, Defense Threat Reduction Agency, P. O. Box 98539, Las Vegas, NV 89193-8518, M/S 573

S. Marshall, Chief, Radiological Health Section, Bureau of Health Protection Services, 1179 Fairview Drive, Suite 201, Carson City, NV 89701-5405

E. A. Tinney, Bureau of Health Protection Services, 1179 Fairview Drive, Suite 201, Carson City, NV 89701-5405

P. J. Liebendorfer, Nevada Division of Environmental Protection, 333 W. Nye Lane, Carson City, NV 89706-0866

M. D. McKinnon, Nevada Division of Environmental Protection, 1515 E. Tropicana Ave., Suite 395, Las Vegas, NV 89119

L. Franks, Bureau of Health Protection Services, 620 Belrose Street, Las Vegas, NV 89158-5242

L. W. Nattrass, Lawrence Livermore National Laboratory, P. O. Box 808, Livermore, CA 94550-9234, M/S L-149

P. S. Raglin, Sandia National Laboratories, P. O. Box 5800, Albuquerque, NM 87185-0136

J. M. McAfee, Los Alamos National Laboratory, M/S D420, Los Alamos, NM 87545

P. W. Tomiczek Jr., Environmental Management, Bechtel Nevada, P. O. Box 98521, Las Vegas, NV 89193-8521, M/S NLV102

D. A. Watson, Environmental Operations, Bechtel Nevada, P. O. Box 98521, Las Vegas, NV 89193-8521, M/S NLV022

Public Reading Facility, Nevada Operations Office, National Nuclear Security Administration, U.S. Department of Energy, P. O. Box 98521, Las Vegas, NV 89193-8521, M/S NLV040

B. D. Becker, Waste Management Department, Bechtel Nevada, P. O. Box 98521, Las Vegas, NV 89193-8521, M/S NTS403

M. L. Brown, Program Manager, IT Corporation, 2621 Losee Road, Building B-1, Suite 3050, North Las Vegas, NV 89030, M/S 438 